\title{
Su ve Arazi Tabanlı Rekreasyon Olanaklarının Belirlenmesi: Ankara Güneyi Alt Havzası Örneği
}

\section{Emel BAYLAN ${ }^{\mathscr{P}}$ (D), Zuhal DİLAVER ${ }^{2}$ (D) Ayşe DEMIR $^{3}$ (D), Ekin OKTAY ${ }^{1}$ (D)}

${ }^{1}$ Yüzüncü Yıl Üniversitesi, Mimarlık ve Tasarım Fakültesi, Peyzaj Mimarlığı Bölümü, Tuşba, Van, ${ }^{2}$ Ankara Üniversitesi, Ziraat Fakültesi, Peyzaj Mimarlığı Bölümü, Aydınlıkevler, Ankara, ${ }^{3}$ Ankara Üniversitesi, Fen Bilimleri Enstitüsü, Peyzaj Mimarlığı Anabilim Dalı,

Aydınlıkevler, Ankara

$\bowtie$ : emelbaylan@yyu.edu.tr

\section{ÖZET}

$\mathrm{Su}$ ve arazi tabanlı rekreasyon olanakları spekturumu (SAROS), rekreasyon olanaklarının belirlenmesinde ve rekreasyon kaynaklarının sürdürülebilirliğine yönelik karar üretmede, rekreasyon planlaması ve yönetiminden sorumlu kurumlara rehberlik eden bir araç olarak öne çıkmaktadır. Bu çalışmada, nüfus yoğunluğu ve kentsel yayılma ile birlikte kent çeperindeki doğal ve kırsal alanlar üzerindeki baskının ve rekreasyonel kullanım talebinin her geçen gün arttığı Ankara İli'nin Güney Alt Havzası'nın SAROS sınıflarının belirlenmesi amaçlanmıştır. Bu kapsamda Havza, dört peyzaj mimarından oluşan uzman grubu tarafindan yapılan arazi incelemeleri ve CORINE 2012 arazi kullanımı/arazi örtüsü özellikleri temel alınarak, fiziksel, sosyal ve yönetimsel ortam parametrelerine göre SAROS sınıfları kapsamında değerlendirilmiştir. Alandaki SAROS sınıflarının tanımlanması için; veri toplama, belirlenen ortam parametrelerini ARCGIS 10.2 ortamında analize hazırlama, analiz, sınıflandırma, ağırlıklandırma ve çakıştırma iş̧lemleri uygulanmıştır. Analizler sonucunda Havza'nın farklı bölümlerinin fiziksel ortam parametreleri bakımından; gelişmiş kırsal, kentsel ve kent çeperi sınıfinda olduğu belirlenmiştir. Sosyal ortam özelliklerinin genel olarak, doğal kırsal ve gelişmiş kırsal sınıfta olduğu belirlenen Havza, yönetimsel özellikler bakımından yabanıl ortam sınıftadır. Her bir ortam parametresinin ağırlıklandırılarak çakıştırılması sonucunda; Havza'da yarı-yabanıl sınıftaki alanların alansal büyüklük bakımından birinci, doğal kırsal sınıftaki alanların ikinci ve üçüncü sırada ise yabanıl sınıf alanların olduğu tespit edilmiştir. Buna göre Havza, yabanıldan kentsele kadar çeşitlilik gösteren farklı rekreasyon ortam özellikleri ve olanakları ile kullanıcıların farklı rekreasyon ihtiyaçlarına ve deneyim taleplerine karşılık verebilecek potansiyele sahiptir. Alanın rekreasyon olanaklarının sürdürülebilirliği için yabanıl, yarı yabanıl ve doğal kırsal sınıftaki bölgelerin korunması gerekmektedir. Buna göre Ankara İli Güney Alt Havzası'ndaki mevcut rekreasyonel alanlarda ziyaretçi yoğunluğunun sınırlandırılması, kentsel karakterdeki rekreasyon faaliyetleri yerine; ekoturizm, kırsal turizm ve doğa koruma faaliyetlerinin teşvik edilmesi gerekmektedir.
Article History

Geliş Tarihi : 22.04.2018

Kabul Tarihi : 10.09.2018

\section{Keywords}

rekreasyon planlama ve yönetimi, kent çeperi, kırsal alanlar, rekreasyon olanakları spekturumu (ROS),

Mogan ve Eymir Gölleri

\section{Research Article}

Identifying Water And Land Based Recreation Opportunities: Case Study on Southern Sub-Basin of Ankara

\begin{abstract}
Water and Land Recreation Opportunity Spectrum (WALROS), stands out as a tool that guides the institutions responsible for recreation planning and management in determining recreation opportunities and making decisions on the sustainability of recreation resources. This study aims to identify WALROS classes of the Southern Sub-Basin of Ankara Province, where the population density and urban sprawl put pressure on the natural and rural resources in
\end{abstract}

Article History

Received : 22.04.2018

Accepted : 10.09.2018 
the urban fringe and there is a day by day growing demand for recreation use. In this context, the basin is evaluated based on land surveys and the CORINE 2012 land use/land cover features by the expert group of four landscape architects under the WALROS classifications according to physical, social and managerial parameters. In order to identify WALROS classes; data collection, preparing the specified setting parameters for analysis, analysis, classification, weighting and overlay operations have been implemented in ArcGIS10.2. As a result, the basin is determined under the classifications of developed-rural, urban and sub-urban in terms of physical setting parameters. In general, the basin also determined as natural-rural and developed-rural based on social setting features and primitive based on managerial features. After overlaid by weighting of each parameter, semi-primitive class is ranked as the first in terms of areal size, natural-rural class is the second and primitive class ranked as the third in the basin. Consequently, the basin has the potential to respond to different recreation needs and experience demands with different recreation ambient properties and facilities which vary from primitive to urban. For the sustainability of the area's recreation opportunities, primitive, semi-primitive and natural-rural class areas must be protected. Accordingly, limiting visitor intensity in existing recreational areas and instead of urban characterized recreational activities, ecotourism, rural tourism or nature conservation activities need to be encouraged in the South Sub-Basin of Ankara Province.

Keywords
recreation planning and
management,
urban fringe,
rural areas,
recreation
specturum (ROS), opportunities
Mogan and Eymir Lakes

Research Article

To cite : Baylan E, Dilaver Z, Demir A, Oktay E 2019. Su ve Arazi Tabanlı Rekreasyon Olanaklarının Belirlenmesi: Ankara Güneyi Alt Havzası Örneği. KSÜ Tarim ve DoğaDerg 22(1) : 106-121, 2019. DOI:10.18016/ ksutarimdoga.vi.417721

\section{GíRiş}

Gün geçtikçe büyüyen ve nüfusu her geçen gün artan kentlerde yaşayan insanlar, monoton ve yorucu yaşam temposundan, psikolojik ve sosyo-kültürel sorunlardan uzaklaşmak ve kendilerini yenilemek için rekreasyon faaliyetlerine yönelmektedir. Rekreasyonun farklı tanımları incelendiğinde; gönüllü olarak, eğlenme, rahatlama ve öğrenme amaciyla, iş dışındaki boş zamanlardan yararlanarak yapılan çeşitli faaliyetleri içeren bir kavram olduğu anlaşılmaktadır (Karahan ve Orhan, 2009; Tanrıvermiş, 2000). Rekreasyon faaliyetlerine katılan insanların amaçları geniş bir yelpazede çeşitlenebilir. Bu amaçların birkaçı çoğu zaman birarada bulunabilir (Gürer, 2014). Yaşam kalitesini iyileştirme çabalarında, rekreasyon olanaklarına erişimin sağlanması ve bu olanakların iyileştirilmesi, boş zaman faaliyetlerinin yönetiminden sorumlu kurumların önemli görevlerindendir (Aukerman, 2011).

Kişilerin rekreasyon deneyiminin kalitesi ve rekreasyon kaynaklarının sürdürülebilirliği için yöneticilerin, rekreasyonel alanların yerel, bölgesel ve hatta bazı durumlarda ulusal ölçekteki rekreasyonel rolünü belirlemesi gerekmektedir. Bir orman, göl ya da nehir, bölgesel ya da ulusal rekreasyon olanakları sisteminin bir parçasıdır. $\mathrm{Bu}$ sistemin tek bir parçasında ya da tek bir alanda, farklı rekreasyon kullanıcı gruplarının her birine her türlü rekreasyon deneyimini sağlayacak olanakların yaratılması akılcı ve sürdürülebilir değildir. Rekreasyon planlaması ve yönetimi olmaksızın, kent çeperindeki doğal ve kırsal alanlarda gerçekleşen rekreasyon faaliyetleri ve kentte yaşayanların bu alanlara yönelik her geçen gün artan rekreasyon talebi, bu peyzajlar üzerindeki baskıyı artırmaktadır. Bu durum, kentlere ve yakın çevresine doğal ve kültürel yaşam destek kaynakları sunan, kent içindeki ve çevresindeki doğal ve kırsal alanların sürdürebilirliğini tehdit ederken, bu alanlara yönelik rekreasyon planlama ve yönetiminin, kentsel ya da bölgesel alan kullanım planlarına dahil edilmesini gerektirmiştir (More ve ark., 2003). Bu bağlamda söz konusu alanın, bölgesel rekreasyon olanakları sisteminde belirli rekreasyon işlevlerini üstlenecek biçimde, rekreasyon kaynaklarının ve faaliyetlerinin sürdürülebilirliğine yönelik rekreasyonel alan planlanmasına ihtiyaç duyulmaktadır (Stenseke ve Hansen, 2014).

$\mathrm{Bu}$ kapsamda günümüzde gelişmiş ülkelerde rekreasyon planlaması ve yönetiminde, çeşitli yönetim stratejileri ve ilkeleri benimsemektedir. Bu yönetim ilkelerinden bazıları;

- $\quad$ etkili rekreasyon planlama ve yönetimi için doğru ve kapsamlı bilginin temin edilmesi ve üretilmesi; 
- rekreasyon alanlarinda hem rekreasyon olanaklarının sağlanması hem de rekreasyon kaynaklarının korunması ve rekreasyon deneyiminin kalitesinin iyileştirilmesi;

- $\quad$ rekreasyon olanaklarında çeşitliliği sağlamaya yardımcı olmak için Rekreasyon Olanakları Spekturumu'nun (ROS) kullanılması ve

- $\quad$ "hedeflerle yönetim çerçevesi"nin rekreasyon yönetimine rehberlik etmesidir (Manning ve Anderson, 2012; Harshaw ve ark., 2015).

Belirtilen temel ilkeler çerçevesinde gerçekleştiren rekreasyon planlama ve yönetiminde, doğal ve kültürel rekreasyon kaynaklarının sürdürülebilirliği ile birlikte kullanıcıların rekreasyon deneyiminin ve rekreasyon tesis ve hizmetlerinin iyileştirilmesi hedeflenmektedir. Belirtilen hedefleri ve ilkeleri benimseyen rekreasyon planlaması çalışmaları; rekreasyon olanaklarının çeşitliliğinin korunması (Finley, 1990), rekreasyon alanlarının kapasitesinin belirlenmesi, rekreasyonel hizmet kalite standartlarının belirlenmesi, kontrolsüz kaynak kullanımının önlenmesi, arazi kullanımının dengelenmesi ve rekreasyonun çevresel ve sosyal etkilerinin belirlenmesi (Soykan, 2000) gibi yararlar sağlamaktadır.

Rekreasyon planlama ve yönetim sürecinin koşulları ve amaçları; söz konusu peyzajın fiziksel ve sosyokültürel karakteristiklerine, arazi kullanım biçimine, erişilebilirliğine, alandan beklenen rekreasyon deneyimlerine ve yönetsel süreçlere göre farklılık göstermektedir (Andkjær ve Arvidsen, 2015; Stenseke ve Hansen, 2014). Bu kapsamda, rekreasyon ve peyzaj yönetimi süreçlerine rehberlik etmek üzere, rekreasyon olanaklarının sistematik envanteri ve değerlendirmesine ihtiyaç duyulmaktadır. Amerika Birleşik Devletleri, Kanada, İsveç, Finlandiya gibi gelişmiş ülkelerde rekreasyonel alan planlaması sürecinde, ilgili alan kullanım, peyzaj planlama ve yönetim süreçlerine temel bilgileri sağlamak üzere, mevcut doğal ve kültürel rekreasyon olanaklarının ve peyzaj özelliklerinin envanteri ve değerlendirmesi için temel olarak, Rekreasyon Olanakları Spekturumu (ROS) yaklaşımını benimseyen çeşitli analiz ve değerlendirme araçları kullanılmaktadır (Finley, 1990; Manfredo ve ark., 1996; More ve ark., 2003; Harshaw ve ark., 2015). ROS, mevcut rekreasyon deneyimi ortamları, mevcut ve olası rekreasyon faaliyet tipi ve kullanıc beklentilerinin kapsamı hakkında plancı, yönetici ve kullanıcılara bilgi sağlamaktadır. Bunun yanı sıra ROS, rekreasyon olanağı sağlamada zorluklarla karşılaşılan; nüfusun arttığ d durumlarda ya da insan faaliyetlerinin ve yapılarının yayılım gösterdiği kent çeperinde/doğal alanlarda karar üretimine yardımcı olmak için de kullanılabilmektedir.

İnsanlar çok çeşitli rekreasyon faaliyetleri arasından genellikle suya dayalı rekreasyon faaliyetlerini ve bu tür faaliyetleri gerçekleştirebilecekleri, su kıyılarını ve bunların yakın çevresini tercih etmektedir (Tanrıvermiş, 2000). Denizden uzak alanlarda; göl, gölet, akarsu gibi iç sular ve bunların kıyıları da zengin rekreasyon firsatları sunduklarından rekreasyon için tercih edilen alandandır. Örneğin, doğal ve kültürel kaynaklar üzerinde büyük baskı yaratan kitle turizmi, deniz kıyılarında yaygin olarak görülürken, bu kaynakların korunması bakış açısını benimseyen rekreasyonel faaliyetler olan ekoturizm faaliyetleri ise bireysel ya da gruplar halinde, iç sularda ve bunların yakın çevresinde de gerçekleştirilebilmektedir (Tanrıvermiş, 2000; Karahan ve Orhan, 2009). Su ve arazi kaynaklarının biçimlendirdiği kent çeperindeki kırsal peyzajlar, olta balıkçılığı, güneşlenme, yüzme, kanoculuk,doğa yürüyüşü, doğa fotoğrafçılığ $\breve{g}_{1}$ kuş ve kelebek gözlemciliği, bitki gözlemciliği, tarım ve çiftlik turizmi, küçük kasaba/köy turları yapma, kırsal mirası tanıma sportif avcılık, bisiklet binme, at binme, gibi farklı rekreasyon faaliyetleri için önemli potansiyellere sahiptir. Bu bağlamda, su ve arazi kaynaklarının biçimlendirdiği kent çeperindeki peyzajlarda, kentliler ve yerel halk, rekreasyon, ekoturizm ve doğa koruma sürecinde etkileşim içinde olabilmektedir.

Arazi ve su öğelerinin peyzajin temel karakteristiklerini ve rekreasyon faaliyetlerini belirlediği peyzajlarda, rekreasyon planlaması ve yönetiminde kullanılmak üzere, rekreasyon kaynak ve olanaklarının envanterine, analizine ve rekreasyon olanaklarının çeşitliliğinin korunmasına yönelik olarak "Su ve Arazi Rekreasyon Olanakları Spektrumu" (SAROS) (The Water and Land Recreation Opportunity Spectrum-WALROS) (Aukerman, 2011) kullanılmaktadır. SAROS, su ve arazi kaynaklarının birlikteliğinde biçimlenen su havzası gibi geniş ölçekli peyzajlarda rekreasyon planlaması ve yönetiminde, söz konusu peyzajın ve içinde yer aldığı bölgenin, fiziksel, sosyal ve yönetimsel özelliklerinin birlikte ele alınmasına olanak vermektedir. Böylece, peyzajın özelliklerinin bölge ya da havza ölçeğinde ele alınmasını sağlayan bir araç olarak SAROS, plancılara ve yöneticilere, alanın doğal ve kültürel peyzaj özelliklerine özgü, su ve araziye dayalı rekreasyon olanaklarının sürdürülebilirliğini ve çeşitliliğini sağlamaya yönelik ve aynı zamanda, kullanıcı ihtiyaçlarına cevap verecek ve maliyet etkin kararların üretilmesine imkan sunmaktadır.

Bu kapsamda çalışmanın amacı; Ankara Güneyi Alt Havzası su ve arazi kaynaklarının, alanla ilişkili rekreasyon planlama ve yönetimi çalışmalarına bilgi sağlamak üzere, SAROS sinıflarına göre tanımlanmasıdır. Elde edilen bulgular çerçevesinde, alanın dış mekan rekreasyon olanaklarının planlanması ve yönetimine yönelik, araştırma ve uygulama önerilerinde bulunulmuştur. 
Rekreasyon Planlama, Rekreasyon Olanakları Spektrumu (ROS); Su ve Arazi Rekreasyon Olanakları Spektrumu (SAROS)

Rekreasyon Olanakları Spektrumu (ROS), rekreasyonel kaynak yönetimi sürecinde, arazi planlaması ve yönetimi çalışmalarının karar üretme aşamasında, mevcut durumun tanımlanmasina yönelik araçlardan biridir (Manfredo ve ark., 1996). Spektrum; rekreasyon olanaklarının çeşitliliğini temel almaktadır. Rekreasyon olanağı; "bir kullanıcı için, tercih ettiği bir ortamda, arzu ettiği tatmin edici deneyimleri gerçekleştirmek amacıyla, tercih ettiği bir faaliyete katılmak için gerçek bir seçeneğin bulunma durumu"dur (Anonymous 1998). ROS envanter sistemi; insanlarm peyzajdan belirli rekreasyonel deneyimleri beklediği varsayımı üzerine kurulmuştur ve arazi yöneticilerinin, rekreasyon beklentileri çerçevesinde, insanların uygun alanlara yönlendirilebilmesi gerektiği düşüncesini temel almaktadır (Finley, 1990; Manfredo ve ark., 1996).

ROS'un ve rekreasyon yönetim sürecinin üç temel bileşeni; ortam, faaliyet ve deneyimdir. Ortam; rekreasyonel faaliyetlerin gerçekleştiği, belirli deneyimlerin ve bağlantılı yararların gerçekleşmesine katkı sağlayan; peyzajın biyofiziksel, sosyal ve yönetim özelliklerin oluşturduğu bir çevre olarak tanımlanmaktadır. Faaliyetler; söz konusu peyzajda insanların gerçekleştirdiği, içinde bulunduğu rekreasyonel eylemler, davranışlardır. Deneyimler; rekreasyon ortamlarındaki rekreasyon faaliyetlerinden psikofizyolojik çıktıların bütünüdür (Finley, 1990; Manfredo ve ark., 1996) (Çizelge 1).

Çizelge 1. Rekreasyon olanağı bileşenleri (Aukerman, 2011)

\begin{tabular}{|c|c|c|c|}
\hline Rekreasyon faaliyeti + & Ortam & Deneyim & Yararlar \\
\hline Çok çeşitli faaliyetler & $\begin{array}{l}\text { Fiziksel özellikler } \\
\text { Sosyal özellikler } \\
\text { Yönetimsel özellikler }\end{array}$ & $\begin{array}{l}\text { Çeşitli boyutlarda } \\
\text { Çok duyusal }\end{array}$ & $\begin{array}{l}\text { Bireysel } \\
\text { Toplumsal } \\
\text { Ekonomik } \\
\text { Çevresel }\end{array}$ \\
\hline Yöneticiler tarafindan yönetilir & & $\begin{array}{l}\text { Rekreasyon faaliyetinde } \\
\text { bulunanlar tüketir }\end{array}$ & $\begin{array}{l}\text { Toplumsal } \\
\text { kazanim }\end{array}$ \\
\hline
\end{tabular}

Bu kapsamda ROS, plancılara ve arazi yöneticilerine; farklı rekreasyon olanaklarını, peyzaj karakteristiklerine bağlı olarak, birbirinden farklı arazi kullanım sınıfı spekturumunda tanımlamalarına ve rekreasyon kaynaklarının sürdürülebilir kullanımına yönelik stratejiler geliştirebilmelerine imkan sağlamaktadır. Rekreasyon olanaklarını belirleyen ortam özelliklerinin başında; peyzajın biyofiziksel özellikleri gelmektedir. Rekreasyon olanakların ortaya çıkmasında ve geliştirilmesinde belirleyici olan biyofiziksel peyzaj özelliklerinden ikisi ise; arazi ve su kaynaklarıdır. Bu iki özelliğin belirleyici olduğu peyzajların, rekreasyon olanakları spekturumunun belirlenmesi için "Su ve Arazi Rekreasyon Olanakları Spektrumu" (SAROS) geliştirilmiştir. SAROS; ROS ve Wilderness Recreation Opportunity Spectrum (WROS)'un güncel, yeniden düzenlenmiş; karasal ve su öğelerin biçimlendirdiği alanlarda kullanılmak üzere uyarlanmış halidir (Aukerman, 2011). SAROS, su ve arazi kaynaklarının bulunduğu geniş alanların rekreasyonel planlamasında ve yönetiminde bölgesel bir yaklaşımı geliştirmek ve rekreasyon olanaklarının korunmasına yönelik karar üretme süreçlerini destekleme üzere tasarlanmış, peyzaj ölçeğinde bir araçtır. Bu bağlamda bir alanın ve içinde yer aldığı bölgenin fiziksel, sosyal ve yönetimsel peyzaj özelliklerinin dikkate alınması, rekreasyon plan ve yönetim kararlarının kalitesi ve işlevselliği bakımından önemlidir. $\mathrm{Bu}$ bilgilerin dikkate alınmadığı ve bölgesel yaklaşımın benimsenmediği çalışmalar, tekrar eden rekreasyon faaliyetlerine ve hizmetlerine, gereksiz harcamalara, rekreasyon kaynaklarının zarar görmesine ve toplumun rekreasyon ihtiyaçlarının karşılanmasında yetersizliklere neden olmaktadır.

\section{MATERYAL ve YÖNTEM}

Çalışmanın ana materyalini Ankara'nın Güneyi Alt Havzası ve Havza'daki Mogan ve Eymir doğal gölleri ile İkizce ve Dikilitaş gibi yapay su kaynakları ve bunların çevresindeki arazi kaynakları oluşturmaktadır. Su ve arazi kaynaklarının birbiriyle etkileşim içinde olması ve bu etkileşimin alandaki rekreasyon olanaklarını biçimlendirmesine bağlı olarak, araştırma alanı sınırları Ankara Güneyi Alt Havza'sı sınırları olarak belirlenmiştir. Havza, büyük bir bölümü Ankara ilinin Gölbaşı ilçesi sınırları içinde bulunan, kuzeybatıda Yenimahalle, kuzeyde Çankaya, batıda Bala, güneyde Haymana ilçesi arazilerinden oluşmaktadır ve yaklaşık 128089 ha büyüklüğündedir. 32 mahalle yerleşiminden oluşan Havza'nın hakim arazi kullanımı/arazi örtüsü, tarımdır. Bölge ve ülke ile bağlantısı karayolu ile sağlanan Havza'da ana akslar; Ankara-İstanbul, Ankara-Konya-Adana, Ankara-Eskişehir, Ankara-Samsun devlet karayolları ve Ankara Çevre otoyoludur (Şekil 1). Havza'nın kuzeyinde, büyük bir kısmı Gölbaşı sınırları içinde bulunan, Gölbaşı Özel Çevre Koruma (ÖÇK) Bölgesi yer almaktadır (Şekil 1). 


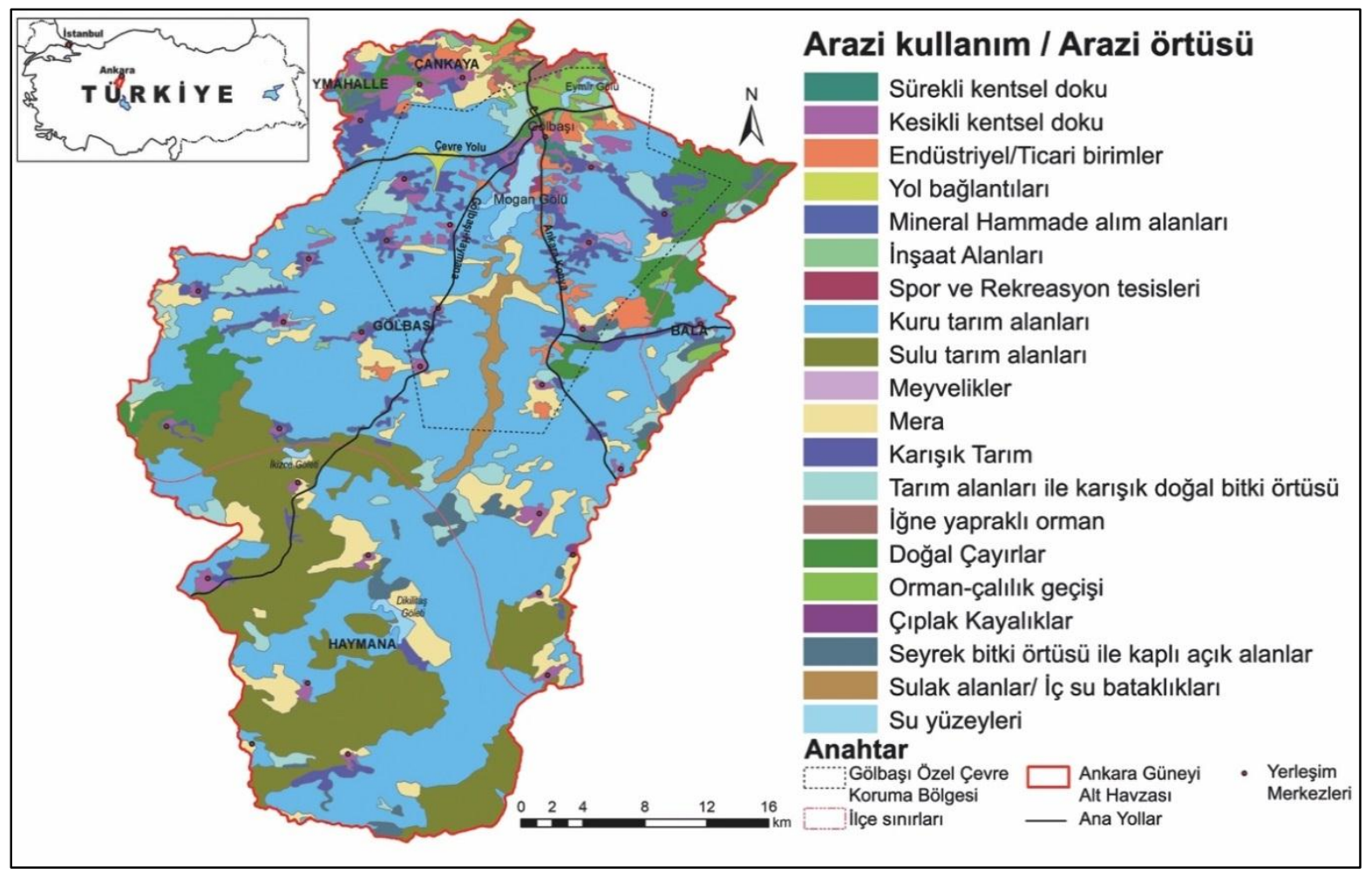

Şekil 1. Araştırma alanının coğrafi konumu ve arazi kullanımı/arazi örtüsü özellikleri

ÖÇK Bölgesi’nin yüzölçümü 27400 hektadır. Havza'nın ve Gölbaşı ÖÇK Bölgesi'nin kuzeyinde yer alan Mogan ve Eymir gölleri, Ankara metropolitan alanının önemli rekreasyon alanlarından biridir. Yine Havza sınırları içinde, kuzeybatı bölümde yer alan Ahlatlıbel mevkii ise Ankara'lllar için bir diğer önemli rekreasyon alanıdır. Araştırma amacı kapsamında; konu ile ilgili türkçe ve yabancı literatür yanında, SAROS fiziksel, sosyal ve yönetimsel envanter cetvelleri materyal olarak kullanılmıştır. Alanı ile ilgili kullanılan materyaller ise sayısal ortamda, 1/25000 ölçekli topoğrafik haritalar üzerinden hazırlanmış Ankara Güneyi Alt Havzası hidroloji haritası ve CORINE 2012 üçüncü düzey verileridir.

Çalışmanın ilk aşamasında araştırma alanına ve konusuna yönelik literatür incelemesi yapılmıştır. Araştırmada, Havza'nın rekreasyon kaynak ve olanaklarının envanteri, analizi ve rekreasyon olanağı sinflarının belirlenmesi amaciyla SAROS sürecinde izlenen adımlar uygulanmıştır. Envanter ve analiz detay derecesi, yüzeyselden ince detaya kadar olabilen SAROS envanteri ve analizleri, bu araştırma kapsamında orta düzey detayda gerçekleştirilmiştir.

Araştırma kapsamında SAROS aracının kullanılmasının nedenleri, bu aracın;

- arazi ve su kaynaklarının birlikte değerlendirilmesine,

- $\quad$ arazi ve su kaynaklarinın ve rekreasyon olanaklarının Havza ölçeğinde değerlendirilmesine,
- $\quad$ havza ölçeğinde belirlenen rekreasyonel olanaklarına ilişkin bilgilerin, il ve bölge ölçeğindeki diğer alan kullanım plan ve politikalarına katkı sağlamaya olanak vermesidir.

Peyzajın -ortamın- özellikleri, faaliyet ve deneyim olanaklarının durumuna ve birlikteliğine göre, rekreasyon olanağı ortamları SAROS kapsamında altı sınıfa ayrılmaktadır (Çizelge 2). Bu sinıfların belirlenmesinde kullanılan başlıca ortam özellikleri Çizelge 3'de verilmiştir.

Araştırmanın arazi ve ofis çalışmalarında, uzman görüş ve değerlendirmelerine dayalı bir yöntem izlenmiştir. Analiz sürecinde, dört peyzaj mimarından oluşan bir uzman grubu tarafından arazi incelemeleri ile arazi kullanımı/arazi örtüsü özellikleri temel alınarak, coğrafi bilgi sistemi araçlarından yararlanılarak analiz ve değerlendirmeler yapılmıştır. $\mathrm{Bu}$ kapsamda araştırmada temel olarak; literatür/ arazi incelemesi ve veri toplama, analize alınacak rekreasyon ortam parametrelerinin belirlenmesi, belirlenen ortam parametrelerini ARCGIS 10.2 ortamında analize hazırlama, analiz, sinıflandırma ve alanın SAROS siniflarının mekansal olarak belirlenmesine yönelik ağırlıklandırma ve çakıştırma işlemlerinin gerçekleştirildiği 5 aşamalı bir yöntem izlenmiştir (Şekil 2). 
Çizelge 2. SAROS rekreasyon ortamı sınıfları ve özellikleri (Aukerman, 2011).

Kentsel Yoğun gelişimin ve yoğun nufusun olduğu kentler ve metropolitan alanlardır. Peyzajın ortam bütününde, insan ürünü yapılar bulunmaktadır.Sanayi, ticari ve yerleşimden oluşan kentsel arazi kullanımı hakimdir. Işıklar, sesler ve kokular kente özgüdür. Doğal öğeler küçük mahalle parklarında, sokaklarda, nehir kıyılarında, ev bahçelerinde görülebilir. $\mathrm{Bu}$ ortamdaki su kaynakları, büyük ölçüde kanallara alınmış ve değişime uğramıştır. Personel, işaretler, hizmetler ve güvenlik gibi öğeleri ile rekreasyon yönetimi belirgin düzeydedir. Rekreasyon faaliyetlerinin çeşitli olduğu, sosyalleşmenin ve bazı alanlarda yoğunlaşmanın görüldüğü kentsel ortamda, rekreasyon faaliyelerinde güvenlik ve kolay erişilebilirlik duygusu hakimdir.

Kent İnsan yapısı öğeler, gelişime ait sesler, kokular ve görüntüler geniş bir alana yayılmıştır.

çeperi Yapılı çevrede, yerleşim ve ticari kullanım biçimi hakimdir. Doğal görünümlü ortamlar, (banliyö) büyük parklarda, yeşil yollarda, yürüyüş yollarında, açık doğal alanlarda, haliç ve diğer ortamı sulak alanlarda bulunmaktadır. Su kaynakları büyük ölçüde kanallara alınmış, ve değiişime uğramıştır. Rekreasyon yönetimi büyük ölçüde belirgindir. Rekreasyon faaliyetlerinde çeşitlilik, sosyalleşme ve bazı alanlarda yoğunlaşma, güvenlik ve kolay erişilebilirlik duygusu yaygın ve belirgindir. Rekreasyon ve rekreasyon dışı kullanımların görüntüsü, sesleri ve kokuları belirgindir ancak hakim değildir.

Gelişmiş $\mathrm{Bu}$ ortamdaki gelişmişlik, kentsel ve kent çeperindeki gelişmişlikten farklıdır; çalışma kırsal çiftlikleri, hayvan çiftlikleri ve beldeleri/ilçeleri içerebilmektedir. Bu ortamda basit bir yol ortam ağı yaygındır. Gelişmişlik mevcut ve belirgin olsa da, bu ortam, orman, su kaynakları, tepelik alanlar, vadiler, sulak alanlar ve tarımsal arazilerin varlığı nedeniyle kırsal niteliktedir. Su kontolü için çeşitli yapılar yaygın olsa da, doğal kıyı kenarı da yaygın olarak görülmektedir. Rekreasyon yönetimi belirgin düzeyde görülse de, kentsel bir ortamdaki kadar kapsamlı değildir. Rekreasyon faaliyetlerinde çeşitlilik, sosyalleşme ve yoğunlaşma, güvenlik ve kolay erişilebilirlik duygusu, kentsel ve kent çeperi ortamından daha düşük düzeydedir. Kentli bir kullanıcının, huzurlu ve günlük yaşamın zorluklarından kaçabildiği yerler mevcuttur.

Doğal Metropolitan alanlardan ve toplumdan oldukça uzaktadır. Peyzajda doğal özellikler ve doğal kırsal kaynaklar hakimdir; gelişmişliği gösteren büyük yapılar nadir görülür. Tarım, turizm ve dış ortam mekan rekreasyonu genelde hakim alan kullanım biçimidir. Gelişmişliğin göstergesi olan görüntüler, sesler ve kokular seyrektir. Su kaynaklarının etrafında doğal görünümlü ortamlar bulunmaktadır; kıyı çizgisi boyunca su kontrol yapılarına ya da diğer yapılara nadiren rastlanır. Rekreasyon yönetimi nadiren görülür. Ziyaretçilerin doğayı hissetme olanakları yaygındır. Rekreasyon faaliyetlerinin çeşitliliği, sosyalleşme ve bazı alanlarda yoğunlaşma, güvenlik ve kolay erişilebilirlik duygusu, dönemsel ve durumsaldır. Bu tür alanlara örnek olarak; tali yolların, tek konutların ve çiftliklerinve benzin istasyonlarının olduğu ve ayrıca, geniş arazilerle ve su yüzeyleri ile sinırlanmış alanlar verilebilir.

Yarı Herhangi bir kent ya da metropolitan alandan uzak, ilçe ve köylerden oldukça uzakta ve yabanıl doğal kaynakların geniş alanlar kapladığı bir ortamdır. Gelişim çok düşük düzeydedir; insan ortam faaliyetlerinden kaynaklı ses ve görüntüler çok azdır. Bu ortamda hafif tarımsal faaliyetler, enerji hatları, hayvancılık, küçük yapılar, eski yollar, tarihi yapılar ve eski maden ocakları gibi insan faaliyetlerinin izleri görülebilir. Su kaynakları geniş araziler içinde yer almaktadır. Devriye, yön işaretleri gibi yönetim araçları nadiren görülür; ziyaretçiler yönlerini, kendi becerileri ve araçları ile bulur. Bu ortamın ziyaretçileri sakinlik ve günlük rutinlerden kaçma isteğindedir. Tesisler basit, kırsal niteliktedir. Issızlığın ve uzaklığın hissedildiği, doğayı hissetme olanaklarının yüksek olduğu bu ortamda, doğal kaynakların korunması oldukça önemlidir. Korunan doğal alanlar ve yaban yaşam alanları bu ortama örnek olarak verilebilir.

Yabanıl Gelişmeden ve yerleşimden oldukça uzakta, doğal kaynaklarının geniş alanlar kapladığı bir ortam alandır. İnsan faaliyetlerine ait görüntüler, ses ve koku çok nadirdir. Su kaynakları ve kıyı çizgisi doğal görünmektedir. Yönetim, ziyaretçilerle işbirliğine dayalıdır ve yönetim faaliyetleri çoğunlukla doğal kaynakların korunmasına, onarımına ve izlenmesine odaklanmıştır. Bu ortamın ziyaretçilerinde; uzaklık, çılgınlık, yanlızlık ve özgüven duygusu hakimdir. Ziyaretçilerin rahatlı̆̆na yönelik hizmetler bu ortam için uygun değildir. Yolu olmayan, geri kalmış, uzak bölgelerde göllerin ya da diğer su kaynaklarının bulunduğu alanlar, milli parklar ya da diğer ulusal/uluslararası korunan doğal alanlar ve yaban yaşam alanları bu ortama örnek olarak verilebilir. 
Çizelge 3. SAROS sınıfları ortam özellikleri göstergeleri (Aukermann 2011).

\begin{tabular}{|c|c|c|}
\hline Fiziksel özellikler & Sosyal özellikler & Yönetimsel özellikler \\
\hline $\begin{array}{l}\text { - Gelişmişlik } \\
\text { (manzarada hakim olan insan } \\
\text { yapısı ögelerin yaygınlık derecesi) } \\
\text { - Büyük } \\
\text { gelişimlerden/su yapısal } \\
\text { uzaklık } \\
\text { düllarından } \\
\text { düzeyi Doğal kaynakların değişim } \\
\text { düzeyi Yerleşime yakınlık hissi } \\
\text { - Doğallık hissi düzeyi } \\
\text { - Su ve hava kalitesi } \\
\text { standartları }\end{array}$ & 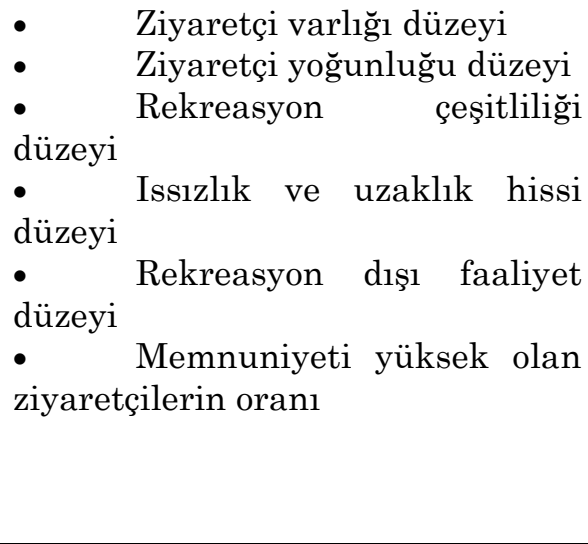 & $\begin{array}{l}\text { - Yönetim yapıları varlığı } \\
\text { düzeyi } \\
\text { - Rekreasyon tesislerine ve } \\
\text { hizmetlerine uzaklık } \\
\text { • Kamusal giriş alanlarına } \\
\text { (örn: otopark, bağlantı yolları) } \\
\text { uzaklık } \\
\text { • Yönetim personeli görme } \\
\text { siklığı düzeyi }\end{array}$ \\
\hline
\end{tabular}

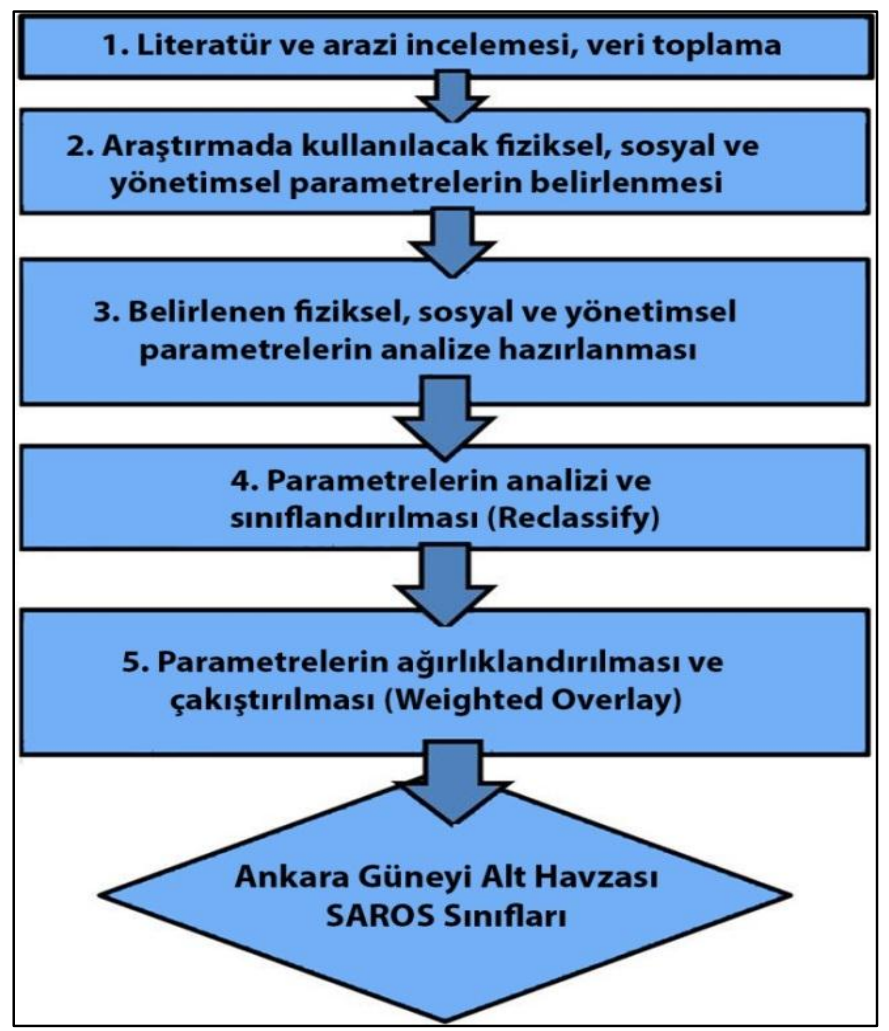

Şekil 2. Araştırmada izlenen aşamalar

1. Literatür ve arazi incelemesi, veri temini: Araştırmanın teorik ve yöntemsel alt yapısının oluşturulması amaciyla rekreasyon, rekreasyon planlaması ve yönetimi, ekoturizm, kırsal turizm, ROS ve SAROS araçları ile ilgili yabancı ve yerli literatür incelenmiştir. Arazi incelemesi kapsamında Ankara Güneyi Alt Havzası'nın farklı bölümlerinde dört peyzaj mimarı tarafından, SAROS sinıfları özellikleri göz önünde bulundurularak gözlemler yapılmıştır. Havza'nın CORINE 2012 arazi kullanımı/arazi kullanımı verileri, Copernicus veri tabanından temin edilmiştir (Anonymous, 2018).

2. Parametrelerinin belirlenmesi: Öncelikle araştırma alanının özellikleri ve verilerin erişilebilirliğine bağlı olarak, SAROS sınıfları analiz ve değerlendirme aşamalarında kullanılacak fiziksel, sosyal ve yönetimsel ortam parametreleri belirlenmiştir. Araştırmanının analiz ve değerlendirme aşa malarında dikkate alınan ortam parametreleri Çizelge 4'te verilmiştir. Ortam parametrelerinin SAROS sınıflarına göre farklılaşan düzey ve ölçüleri Çizelge 5 'de verilmiştir.

3. Belirlenen fiziksel, sosyal ve yönetimsel parametrelerin analize hazırlanması: Belirlenen ortam parametreleri, ARCGIS 10.2'de Spatial Analyst Tools yardımı ile raster formata dönüştürülmüştür. Analizlere katılacak olan tüm veri katmanları 100 metrede $(100 \mathrm{~m} \times 100 \mathrm{~m})$ örneklenmiştir. Buna göre analizler, $10000 \mathrm{~m}^{2}$ boyutlarındaki gridlere örneklenen raster veri katmanları temelinde yapılmıştır.

4. Parametrelerin analizi ve sinuflandırılması: Araştırmada SAROS sınıfları, rekreasyon olanakları bakımından yabanıl özelliklere sahip olan ortamlara en yüksek değer olan 6, kentsel rekreasyon ortam özellikleri gösteren alanlara ise en düşük değer olan 1 verilerek sınıflandırılmıştır (Çizelge 6). Bu aşamada ayrica, bir önceki aşamada raster formata dönüştürülen her bir ortam parametresi için ortak bir değerlendirme birimi elde etmek üzere, SAROS sınıflarının özelliklerinin dikkate alındığ uzman görüşleri çerçevesinde, araştırma alanının arazi kullanım/arazi örtüsü sınıflarına 1-6 değer aralığında puan verilerek yeniden (reclassify) sınıflandırılmıştır (Çizelge 7).

Fiziksel ortam parametrelerinden; büyük yapısal gelişimlerden/su yapılarından uzaklık ve yönetimsel parametrelerden; rekreasyon tesislerine ve hizmetlerine uzakllk parametreleri, yine SAROS sinıflandırmasında kullanılan uzaklık ölçütleri çerçevesinde puan verilerek sinıflandırılmıştır (Çizelge 8).

5. Parametrelerin ağırlıklandırılması ve çakıştırılması: Bir önceki aşamada yeniden siniflandirılan parametrelere son olarak, ağırlıklandırma analizi uygulanmıştır. 
Ağırlıklandırma analizi kapsamında; uzmanların, rekreasyon ortamı parametrelerinin eşit derecede önemli olduğu görüşü çerçevesinde, parametrelere toplamda 1 puan olacak şekilde eşit puan verilip, parametreler bu puan ile çarpılmıştır (Çizelge 9). Daha sonra tüm parametreler toplanmıştır ve sınıflandırılan parametre katmanları doğrudan ağırlıklı çakıştırma/bindirme (weighted overlay) işlemi ile çakıştırılmıştır. Buna göre;10 ortam parametresi katmanı çakıştıralarak, Havza'da kentsel, yarı kentsel, gelişmiş kırsal, doğal kırsal, yarı yabanıl ve yabanıl rekreasyonel olanak sınıfı için uygun alanlar mekânsal olarak belirlenmiş ve tanımlanmıştır.

Çizelge 4. Araştırmada kullanılan SAROS ortam özellikleri parametreleri

\section{Fiziksel özellikler}

- $\quad$ Gelişmişlik düzeyi

- Büyük yapısal gelişimlerden/su yapilarindan (yol, kentsel alan, • barajlar vb.) uzaklık

- Doğal kaynakların değişim

düzeyi

- Doğallık hissi düzeyi

\section{Sosyal özellikler}

Ziyaretçi yoğunluğu düzeyi

Issızlık ve uzaklık hissi düzeyi •

Rekreasyon çeşitliliği düzeyi •

\section{Yönetimsel özellikler}

Yönetim yapıları varlığ̣ düzeyi

Yönetim personeli görme sıklığı düzeyi

Rekreasyon tesislerine ve hizmetlerine uzaklık

Çizelge 5. SAROS sınıflarına göre araştırmada kullanılan ortam parametrelerinin düzeyi (Aukerman, 2011).

\begin{tabular}{|c|c|c|c|c|c|c|c|}
\hline & SAROS Sınıfı & Kentsel & $\begin{array}{l}\text { Kent } \\
\text { Çeperi }\end{array}$ & Gelişmiş Kırsal & $\begin{array}{l}\text { Doğal } \\
\text { Kirsal }\end{array}$ & $\begin{array}{l}\text { Yarı } \\
\text { Yabanıl }\end{array}$ & Yabanıl \\
\hline \multirow{10}{*}{ 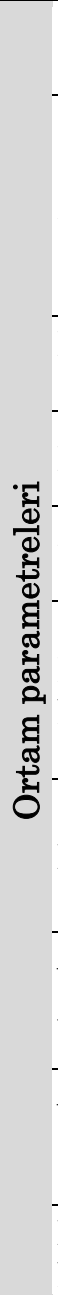 } & Gelişmişlik düzeyi & $\begin{array}{l}\text { çok yüksek } \\
\% 80-100\end{array}$ & $\begin{array}{l}\text { yüksek } \\
\% 50-80\end{array}$ & $\begin{array}{l}\text { lirgin } \\
20-50\end{array}$ & $\begin{array}{l}\text { orta/durumsal } \\
\% 10-20\end{array}$ & $\begin{array}{l}\text { düşük } \\
\% 3-10\end{array}$ & $\begin{array}{l}\text { çok düşük } \\
\% 0-3\end{array}$ \\
\hline & $\begin{array}{l}\text { Büyük yapısal } \\
\text { gelişimlerden (yol, } \\
\text { kentsel alan, } \\
\text { baraj/gölet vb.) uzaklık } \\
\text { düzeyi }\end{array}$ & $<0,8 \mathrm{~km}$ & $0,8-3,2 \mathrm{~km}$ & $3,2-8 \mathrm{~km}$ & $8-13 \mathrm{~km}$ & $13-16 \mathrm{~km}$ & $>16 \mathrm{~km}$ \\
\hline & $\begin{array}{l}\text { Doğal kaynakların } \\
\text { değişisim düzeyi }\end{array}$ & $\begin{array}{l}\text { çok yüksek } \\
\% 80-100\end{array}$ & $\begin{array}{l}\text { yüksek } \\
\% 50-80 \\
\end{array}$ & $\begin{array}{l}\text { belirgin } \\
\% 20-50\end{array}$ & $\begin{array}{l}\text { Orta/nadir } \\
\% 10-20\end{array}$ & $\begin{array}{l}\text { düşük } \\
\% 3-10\end{array}$ & $\begin{array}{l}\text { çok düşük } \\
\% 0-3\end{array}$ \\
\hline & Doğallık hissi düzeyi & $\begin{array}{l}\text { çok düşük } \\
\% 0-3\end{array}$ & $\begin{array}{l}\text { düşük } \\
\% 3-10\end{array}$ & $\begin{array}{l}\text { Kismi/durumsal } \\
\% 10-20\end{array}$ & $\begin{array}{l}\text { belirgin } \\
\% 20^{-50}\end{array}$ & $\begin{array}{l}\text { yüksek } \\
\% 50-80\end{array}$ & $\begin{array}{l}\text { çok yüksek } \\
\% 80-100\end{array}$ \\
\hline & $\begin{array}{l}\text { Ziyaretçi yoğunluğu } \\
\text { düzeyi }\end{array}$ & $\begin{array}{l}\text { çok yüksek } \\
\% 80-100\end{array}$ & $\begin{array}{l}\text { yüksek } \\
\% 50-80\end{array}$ & $\begin{array}{l}\text { belirgin/orta } \\
\% 20-50\end{array}$ & $\begin{array}{l}\text { seyrek/dönems } \\
\% 10-20\end{array}$ & $\begin{array}{l}\text { düşük } \\
\% 3-10\end{array}$ & $\begin{array}{l}\text { çok düşük } \\
\% 0-3\end{array}$ \\
\hline & $\begin{array}{l}\text { Issızlık ve uzaklık } \\
\text { hissi düzeyi }\end{array}$ & $\begin{array}{l}\text { çok düşük } \\
\% 0-3\end{array}$ & $\begin{array}{l}\text { düşük } \\
\% 3-10\end{array}$ & $\begin{array}{l}\text { nadiren/ } \\
\text { dönemsel/ } \\
\text { bölgesel } \\
\text { \%10-20 }\end{array}$ & $\begin{array}{l}\text { belirgin } \\
\% 20-50\end{array}$ & $\begin{array}{l}\text { çok belirgin } \\
\% 50-80\end{array}$ & $\begin{array}{l}\text { çok yüksek } \\
\% 80-100\end{array}$ \\
\hline & Rekreasyon çeşitliliği & $\begin{array}{l}\text { çok yüksek } \\
\% 80-100\end{array}$ & $\begin{array}{l}\text { yüksek } \\
\% 50-80\end{array}$ & $\begin{array}{l}\text { belirgin } \\
\% 20-50\end{array}$ & $\begin{array}{l}\text { dönemsel/ } \\
\text { bölgesel } \\
\text { \%10-20 }\end{array}$ & $\begin{array}{l}\text { düşük } \\
\% 3-10\end{array}$ & $\begin{array}{l}\text { çok düşük, } \\
\text { çok nadir } \\
\% 0-3\end{array}$ \\
\hline & $\begin{array}{l}\text { Yönetim yapıları } \\
\text { varlığı düzeyi }\end{array}$ & $\begin{array}{l}\text { çok yüksek } \\
\% 80-100\end{array}$ & $\begin{array}{l}\text { yüksek } \\
\% 50-80\end{array}$ & $\begin{array}{l}\text { belirgin } \\
\% 20-50\end{array}$ & $\begin{array}{l}\text { durumsal/ az } \\
\% 10-20\end{array}$ & $\begin{array}{l}\text { düşük, } \\
\text { nadir \%0-3 }\end{array}$ & $\begin{array}{l}\text { çok düşük, } \\
\text { çok nadir } \\
\% 0-3\end{array}$ \\
\hline & $\begin{array}{l}\text { Yönetim personeli } \\
\text { görme sıklığı düzeyi }\end{array}$ & $\begin{array}{l}\text { çok yüksek } \\
\% 80-100\end{array}$ & $\begin{array}{l}\text { çok yüksek } \\
\% 50-80\end{array}$ & $\begin{array}{l}\text { belirgin } \\
\% 20-50\end{array}$ & $\begin{array}{l}\text { Durumsal/az } \\
\text { rastlanır } \\
\% 10-20\end{array}$ & $\begin{array}{l}\text { düşük, } \\
\text { nadir \%0-3 }\end{array}$ & $\begin{array}{l}\text { çok düşük, } \\
\text { çok nadir } \\
\% 0-3\end{array}$ \\
\hline & $\begin{array}{l}\text { Rekreasyon tesis ve } \\
\text { hizmetlerine uzaklık }\end{array}$ & $<0,8 \mathrm{~km}$ & $0,8-3,2 \mathrm{~km}$ & $3,2-8 \mathrm{~km}$ & $8-13 \mathrm{~km}$ & $13-16 \mathrm{~km}$ & $>16 \mathrm{~km}$ \\
\hline
\end{tabular}

Çizelge 6. Su-Arazi Rekreasyon Olanak Sınıfları (SAROS) ve sınıflandırma puanları

\begin{tabular}{lllllll}
\hline SAROS Sınıf & Kentsel & $\begin{array}{l}\text { Yarı } \\
\text { Kentsel }\end{array}$ & $\begin{array}{l}\text { Gelişmiş } \\
\text { Kırsal }\end{array}$ & Doğal Kırsal & $\begin{array}{l}\text { Yarı } \\
\text { Yabanıl }\end{array}$ & Yabanıl \\
\hline İndeks (puan) & 1 & 2 & 3 & 4 & 5 & 6 \\
\hline
\end{tabular}


Çizelge 7. Güney Ankara Havzası rekreasyon ortamı parametrelerinin sinıflandırılması

\begin{tabular}{|c|c|c|c|c|c|c|c|c|c|c|}
\hline \multirow[b]{2}{*}{$\begin{array}{l}\text { Alan kullanımı/ } \\
\text { Arazi Örtüsü } \\
\text { Birimi }\end{array}$} & \multicolumn{4}{|c|}{ Fiziksel parametreler } & \multicolumn{3}{|c|}{ Sosyal parametreler } & \multicolumn{3}{|c|}{ Yönetimsel parametreler } \\
\hline & 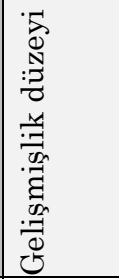 & 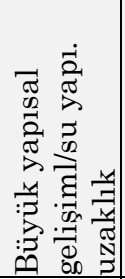 & 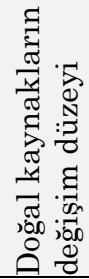 & 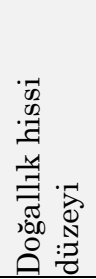 & 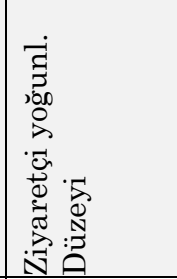 & 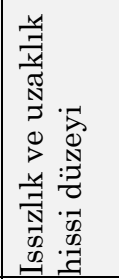 & 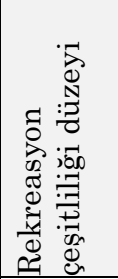 & 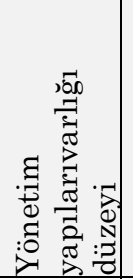 & 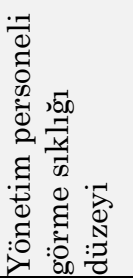 & 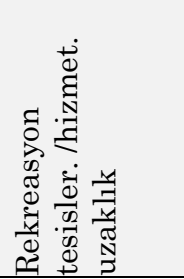 \\
\hline Kentsel-sanayi & 1 & \multirow{7}{*}{$\begin{array}{c}\text { bk. } \\
\text { Tablo } \\
8\end{array}$} & 1 & 1 & $1,4,5,6$ & 1 & 1 & 1 & 1 & \multirow{7}{*}{$\begin{array}{l}\text { bk. Tablo } \\
8\end{array}$} \\
\hline Spor alanı & 2 & & 2 & 2 & 1 & 1 & 2 & 2 & 2 & \\
\hline Tarım alanı & $3,4,5$ & & 3 & 3,4 & $4,5,6$ & 3 & 5 & 6 & 6 & \\
\hline Orman & 6 & & 6 & 5 & 5,4 & 5,6 & 3 & 5 & 5 & \\
\hline Sulak alan & 6 & & 6 & 6 & 3 & 5 & 5 & 5 & 6 & \\
\hline Göller & 6 & & 6 & 5 & $1,2,3$ & $1,2,4$ & $2,3,4$ & $1,4,3$ & $1,2,5$ & \\
\hline Yapay su yüzeyleri & 6 & & 4 & 5 & 4 & 4,5 & 4 & 3,4 & 3,4 & \\
\hline
\end{tabular}

Çizelge 8. Fiziksel ve yönetimsel uzaklık parametrelerinin sınıflandırılması

\begin{tabular}{|c|c|c|c|c|c|c|}
\hline Parametre/ Uzaklık & $<0,8 \mathrm{~km}$ & $0,8-3,2 \mathrm{~km}$ & $3,2-8 \mathrm{~km}$ & $8-13 \mathrm{~km}$ & $13-16 \mathrm{~km}$ & $>16 \mathrm{~km}$ \\
\hline $\begin{array}{l}\text { Büyük yapısal gelişimlerden/su } \\
\text { yapılarından uzaklık }\end{array}$ & 1 & 2 & 3 & 4 & 5 & 6 \\
\hline Rekreasyon tesis ve hizmetlerine uzaklık & 1 & 2 & 3 & 4 & 5 & 6 \\
\hline
\end{tabular}

Çizelge 9. Güney Ankara Havzası rekreasyon ortamı parametrelerinin ağırlık indeksi

\begin{tabular}{lc} 
Parametreler & Ağırlık indeksi (puan) \\
\hline Gelişmişlik düzeyi & 0.1 \\
\hline Büyük yapıssal gelişimlerden/su yapılarından uzaklık & 0.1 \\
\hline Doğal kaynakların değişim düzeyi & 0.1 \\
\hline Doğallık hissi düzeyi & 0.1 \\
\hline Ziyaretçi yoğunluğu düzeyi & 0.1 \\
\hline Issızlı ve uzaklık hissi düzeyi & 0.1 \\
\hline Rekreasyon çeşitliliği düzeyi & 0.1 \\
\hline Yönetim yapıları varlı̆ğ düzeyi & 0.1 \\
\hline Yönetim personeli görme sıklığı düzeyi & 0.1 \\
\hline Rekreasyon tesislerine ve hizmetlerine uzaklık & 0.1 \\
\hline
\end{tabular}

\section{BULGULAR}

Araştırma alanının fiziksel özelliklerinin SAROS siniflandırması

Fiziksel ortam özelliklerinden gelişmişlik düzeyi bakımından, tarımsal araziler, meyvelikler, sulak alanlar, tepelik alanlar ve basit yol ağı gibi özelliklerin varlığına bağlı olarak, Havza'nın genel olarak gelişmiş kırsal ortam karakterinde olduğu tespit edilmiştir. Havza'nın kuzeyinde yer alan Gölbaşı ilçe merkezi ve yakın çevresi ile İncek yerleşimi çevresinin, kentsel doku, ticari birimler, gelişmiş yol bağlantıları ve spor ve rekreasyon alanları gibi alan kullanımlarına bağlı olarak çok yüksek gelişmişlik düzeyi gösterdiği ve buna göre, bu alanların kentsel karakterde olduğu belirlenmiştir. $\mathrm{Bu}$ alanlar dişında Mogan Gölü batısının ve köy yerleşimleri çevresinin de gelişmişlik düzeyi yüksek olarak tespit edilmiştir. Havza'nın kuzeyinde yer alan Eymir Gölü çevresinin, su yüzeyleri, orman ve çalılık alanlarına sahip olmasına bağlı olarak, büyük bölümünün gelişmişlik düzeyi bakımından yarı yabanıl, bir bölümünün ise doğal kırsal karakterde olduğu belirlenmiştir. Havza'nın kuzeybatı, batı ve doğusunda yarı yabanıl karakterde alanlar bulunmaktadır. Mogan Gölü'nün güneyinde yer alan, Çökek Bataklığı ve bu bataklığın kuzeyindeki Güney Sazlıkları'nın gelişmişlik düzeyi bakımından yabanıl karakterde olduğu tespit edilmiştir (Şekil 3). Fiziksel ortam özellikleri, doğal kaynakların değişim düzeyi açısından incelendiğinde, Havza'nın genel olarak; doğal arazi formunun yer yer bozulduğu ancak tepelik alanların, doğal su yüzeyleri yanında sulama göletleri ve kanalları, belirli bölgelerde bulunan orman örtüsü ve bozkır bitki örtüsü, tarımsal arazileri gibi özellikleri ile kırsal arazi kullanım biçiminin ve arazi örtüsünün ağırlıkta olduğu, gelişmiş kırsal karakterde olduğu tespit edilmiştir. Havza'da doğal kaynakların değişim düzeyinin, Gölbaşı ilçesi merkezinde ve doğusunda, Mogan Gölü batısının bir kısmında ve Havza'nın kuzeybatısında yer alan İncek yerleşimi çevresinde çok yüksek ve yüksek olduğu belirlenmiştir. İnsan faaliyetlerinin ve öğelerinin yoğun etkisi altında olan bu alanlar, doğal kaynakların değişim düzeyi açısından kentsel ve kent 
çeperi karakterindedir. Havza'nın kuzeyinde Eymir Gölü çevresinde, kuzey doğusunda ve doğusundaBeynam Ormanları'nın bir bölümünün yer aldığı kesimlerde-doğal kaynak değişim düzeyinin düşük olduğu tespit edilmiştir. Bu alanlar, yarı yabanıl ve doğal kırsal özellikler göstermektedir. Mogan Gölü'nün güneyindeki, doğal özelliklerini büyük oranda koruyan, insan faaliyetlerinden ve bunların etkilerinden uzaktaki Çökek Bataklığı ve yakın çevresinin, yabanıl ve yarı yabanıl karakterde olduğu belirlenmiştir (Şekil 3).

Doğallık hissi düzeyi bakımından Havza genel olarak, kentte yaşayanların huzurlu hissedebilecekleri, günlük yaşamın zorluklarından kaçabildiği yerlerin ve dönemlerin mevcut olduğu, gelişmiş kırsal karakterdedir. Bununla birlikte Havza'nın kuzeyindeki Gölbaşı ilçe merkezi ve yakın çevresinde, kuzeybatısındaki Incek yerleşimi çevresinde, Çevre Yolu ve Ankara-Konya Yolu'nun kuzeyinde doğallık hissi düzeyi düşükten çok düşük düzeye kadar değişim göstermektedir. İnsan faaliyetlerinden kaynaklı ses ve görüntülerin çok az, doğayı hissetme olanaklarının yüksek olduğu, Havza'nın kuzeyindeki Eymir Gölü çevresi ile kuzey doğusunda ve doğusundaki bazı alanlar -örn: Beynam Ormanları'nın bir bölümünün yer aldığı kesimler- doğallık hissi düzeyinin belirgin ve yüksek olduğu; yarı yabanıl ve doğal kırsal karakterde alanlar olarak belirlenmiştir. Sakinliğin hakim olduğu, bitki örtüsü ve fauna özellikleri ile görsel ve işitsel anlamda doğayı hissetme olanaklarının çeşitli olması ve bu bakımdan doğallık hissi düzeyinin çok yüksek olmasına bağlı olarak, Çökek Bataklığı ve çevresinin ise yabanıl karakterde olduğu belirlenmiştir (Şekil 3).

\section{Araştırma alanının sosyal özelliklerinin SAROS siniflandirması}

Sosyal ortam özelliklerinden ziyaretçi yoğunluğu düzeyi bakımından Havza'nın genel olarak, seyrek, dönemsel ve bölgesel ziyaretçi yoğunluğuna sahip olması nedeniyle, doğal kırsal rekreasyon ortamı sınıfında olduğu tespit edilmiştir. Rekreasyonel tesislerin ve kullanımların varlığına ve çeşitliğine bağlı olarak Havza'daki ziyaretçi yoğunluğunun, Mogan Gölü kuzeyinde, Gölbaşı ilçe merkezi ile İncek yerleşimi çevresindeki rekreasyon alanlarında çok yüksek olduğu tespit edilmiştir. Mogan Gölü'nün doğu ve batı kıyılarında ise ziyaretçi yoğunluğu yüksek düzeydedir. Buna göre, Mogan Gölü yakın çevresi, Gölbaşı ilçe merkezi ve İncek yerleşimi yakın çevresi ziyaretçi yoğunluğu bakımından kentsel sınıftadır. Havza'nın kuzeyinde yer alan Eymir Gölü çevresi ve kuzeybatı kesimleri ise ziyaretçi yoğunluğunun görece düşük olmasına bağlı olarak, yarı yabanıl sınıftadır. Havza'nın iç kesimlerinde yer alan Çökek Bataklığı ve çevresinin, çok düşük ziyaretçi yoğunluğuna sahip olması nedeniyle yabanıl sınıfta olduğu belirlenmiştir (Şekil 4).

Issızlık ve uzaklık hissinin belirli bölgelerde ve dönemlerde yaşandığı Havza, bu özellik bakımından genel olarak, gelişmiş kırsal sınıf özellikleri göstermektedir. Mogan Gölü kuzeyinde, Gölbaşı ilçe merkezinde ve diğer yerleşim alanlarında ise ıssızlık ve uzaklık hissi çok düşük düzeydedir. Rekreasyon çeşitliliğinin seyrek, dönemsel ve bölgesel olduğu Havza, bu özellik bakımınından genel olarak, doğal kırsal sinıftadır.

Havza'nın kuzey batı kesimlerinde, İncek yerleşimi yakın çevresindeki bazı bölgeler ile Mogan Gölü’nün kuzeyi ve batı kıyıları ile doğu kıyısındaki bazı bölgeler, rekreasyon çeşitliliğinin yüksek olmasına bağlı olarak kent çeperi rekreasyon ortamı sınıfındadır. Havza'nın iç kesimlerinde yer alan Çökek Bataklığı çevresi çok düşük rekreasyon çeşitliliği ile yabanıl rekreasyon ortamı sınıfındadır (Şekil 4).

\section{Araştırma alanının yönetimsel özelliklerine göre} SAROS siniflandirması

Araştırma alanı yönetimsel ortam özelliklerinden, yönetim yapıları varlığı düzeyi bakımından incelendiğinde, Havza'da genel olarak yönetim hizmetlerinin, yönetim yapılarının, idari ofislerin, yönlendirme ve bilgilendirme tabelalarının, kilometre işaretlerinin, güvenlik aydınlatmalarının ve giriş kapılarının varlık düzeyinin çok düşük olduğu ve nadir görüldüğü tespit edilmiştir. Buna göre Havza yönetim yapıları varlığı düzeyi bakımından genel olarak; yabanıl rekreasyon ortamı sinıfindadır.

Ancak Havza'da, Mogan Gölü yakın çevresinde, Gölbaşı ilçe merkezi ve yakın çevresinde, İncek yerleşimi çevresinde ve yakınındaki rekreasyonel alanlarda yönetim yapılarının varlığı yüksek düzeydedir. Buna göre Havza'nın kuzey ve kuzeybatısında yer alan bu bölgeler yönetim yapıları varlığı düzeyi bakımından; kentsel sınıfta olduğu belirlenmiştir (Şekil 5).

Araştırma alanının büyük bir bölümünde; yönetici, polis, güvenlik görevlisi, giriş personeli, bakım işçileri, can kurtaranlar, rehber gibi yönetim personellerini görme olasılığının çok düşük olduğu tespit edilmiştir. Buna göre, yönetim personeli görme sıklığı düzeyi bakımından Ankara Güneyi Alt Havzası'nın büyük bölümü, yabanıl karakterdedir. Bununla birlikte Havza'nın kuzeyinde, alan yönetimin görece daha gelişmiş olduğu ve yönetim personeli görme sıklığı düzeyinin yüksek olduğu Mogan Gölü çevresi, Gölbaşı ilçe merkezi ve çevresi ile İncek-Ahlatlıbel rekreasyon alanı çevresinin ise kentsel karakterde olduğu belirlenmiştir. $\mathrm{Bu}$ alanların giriş bölgelerinden ve merkezlerinden uzaklaştıkça, yönetim personeli görme sıklığı düzeyinin azaldığı tespit edilmiştir (Şekil 5). 


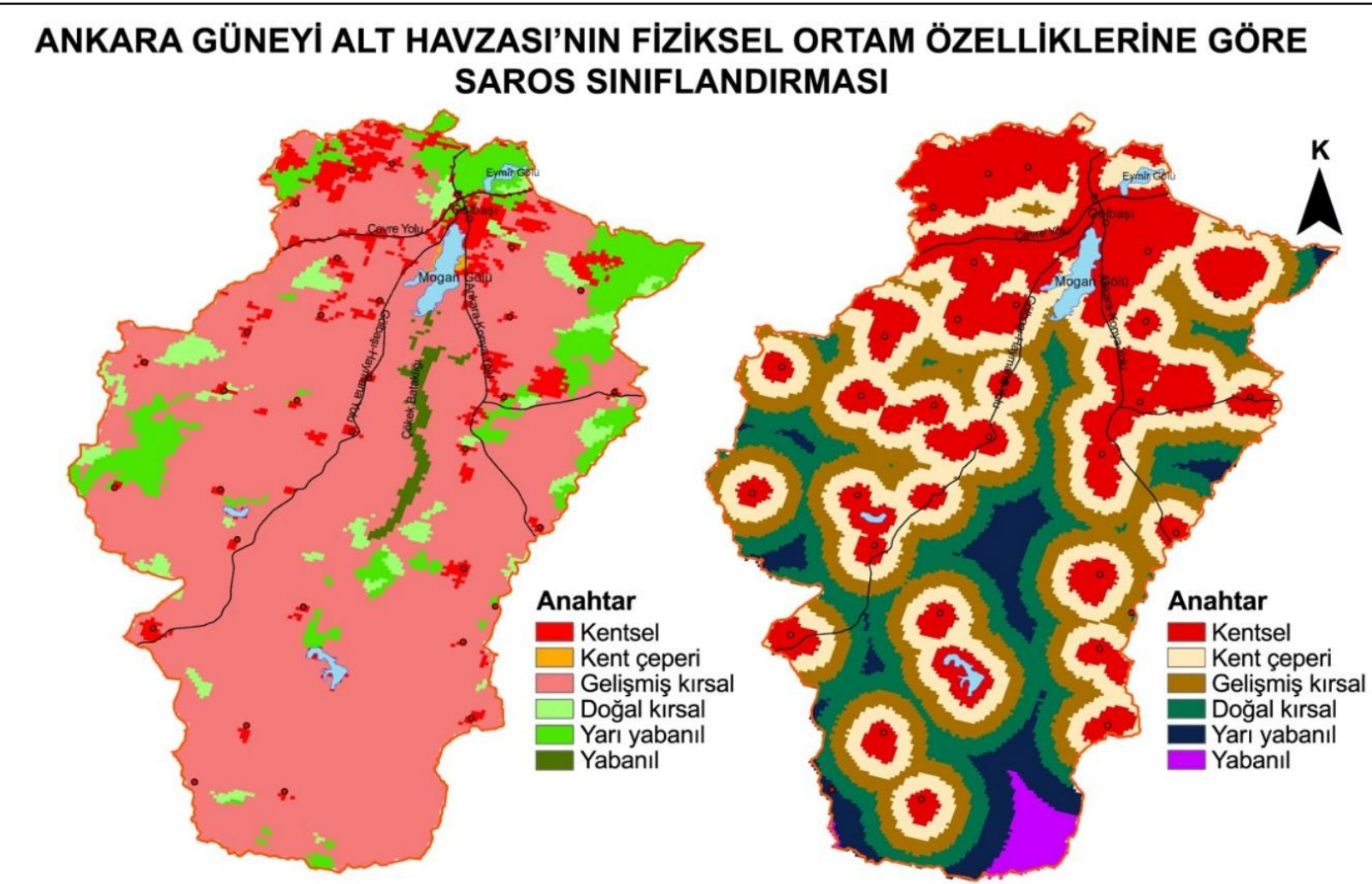

Gelişmişlik düzeyi

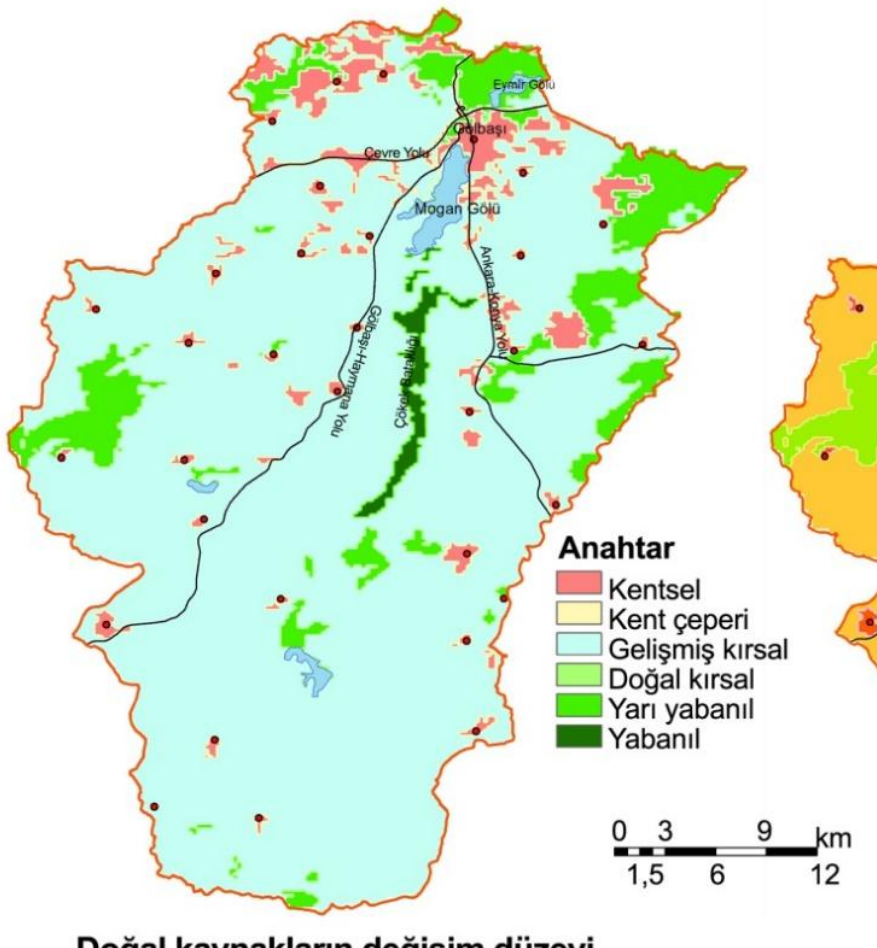

Doğal kaynakların değişim düzeyi
Büyük yapısal gelişimlerden/su yapılarından uzaklık

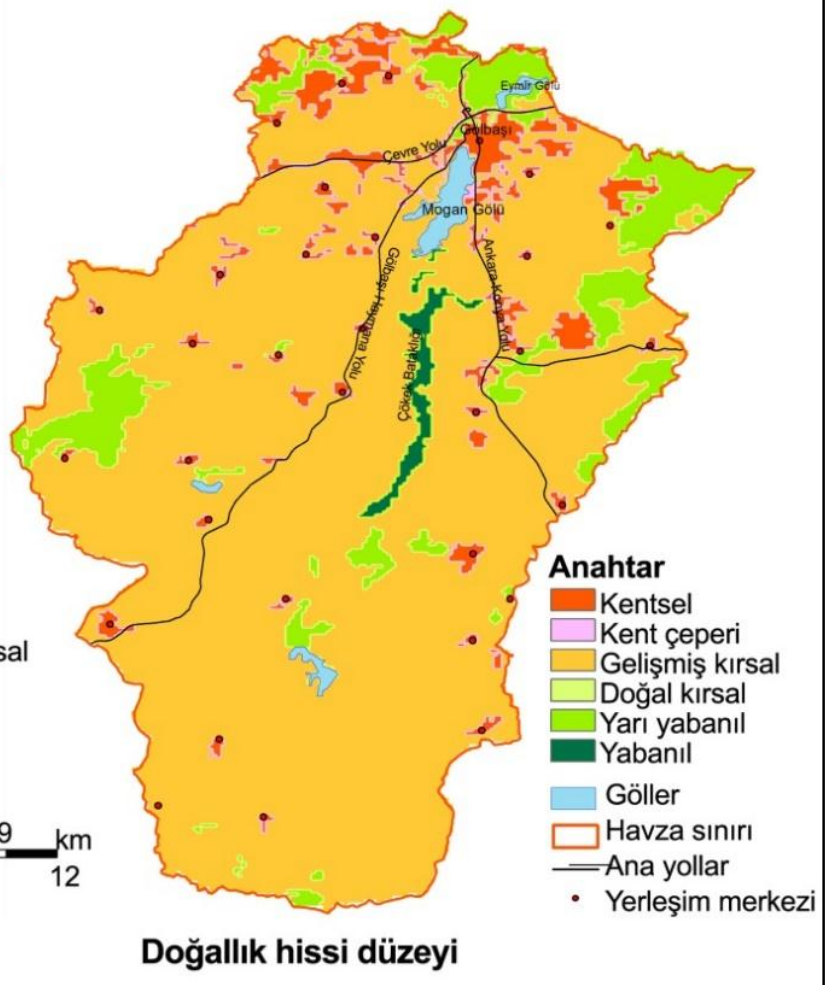

Doğalık hissi düzeyi

Şekil 3. Ankara Güneyi Alt Havzası'nın fiziksel ortam özelliklerine göre SAROS sınıflandırılması 


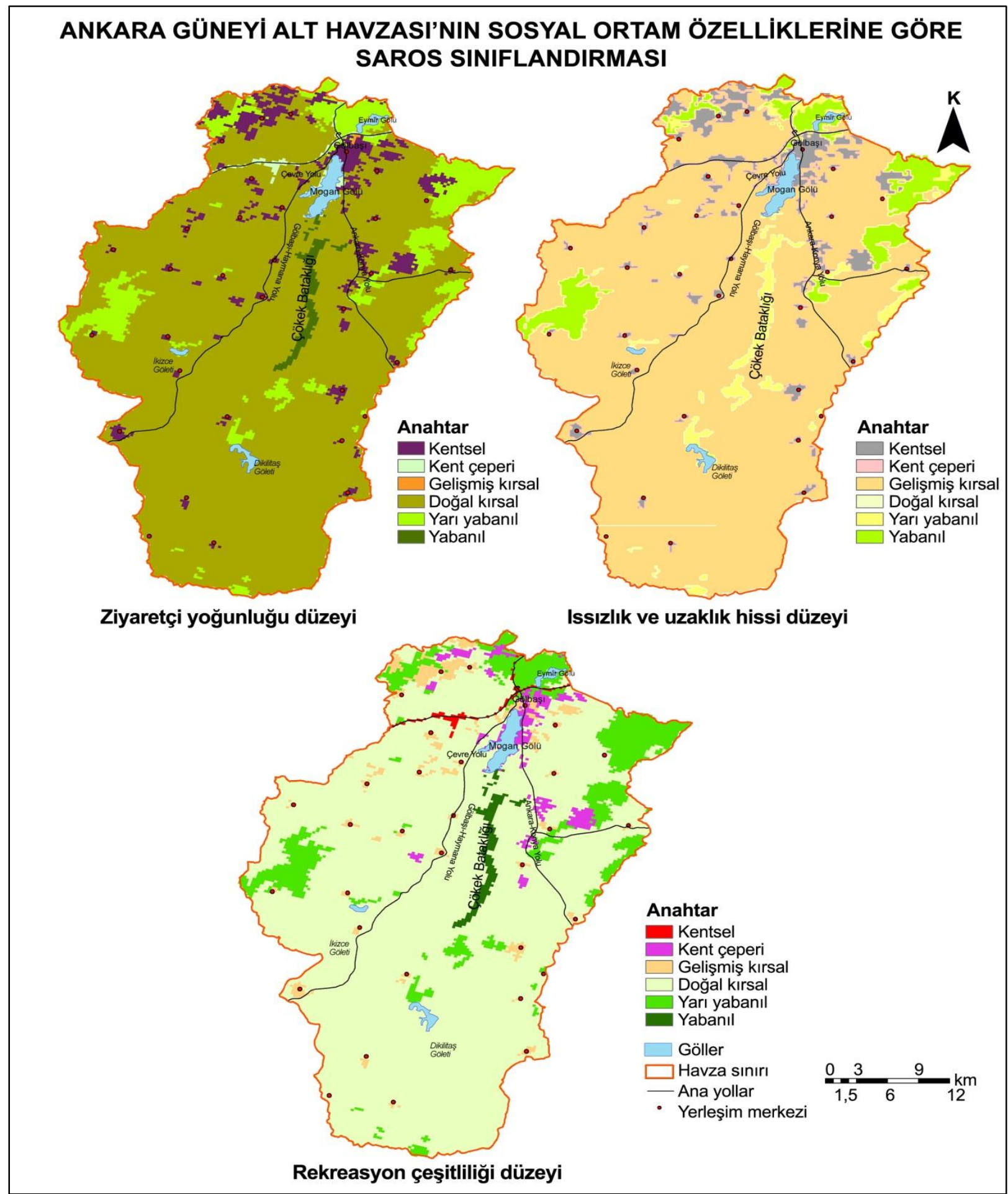

Şekil 4. Ankara Güneyi Alt Havzası'nın sosyal ortam özelliklerine göre SAROS sınıflandırılması

Araştırma alanının büyük bir bölümünde, kamp alanlarına, restoranlara, mağazalara, benzin istasyonlarına, amfi tiyatrolara, piknik alanlarına, oyun alanlarına ve ziyaretçi merkezlerine uzaklık 16 km'den fazladır. Buna göre, rekreasyon tesis ve hizmetlerine uzaklık bakımından Ankara Güneyi Alt Havzası'nın büyük bölümü, yabanıl rekreasyon ortamı sinıfındadır. Havza'nın kuzeyinde, rekreasyon tesis ve hizmetlerine uzaklığın 1 km'den az olduğu Mogan Gölü yakın çevresi, Eymir Gölü yakın çevresi,
Ahlatlıbel ve İncek rekreasyon alanları yakın çevresinin ise rekreasyon tesis ve hizmetlerine uzaklık bakımından, kentsel ortam sinıfında olduğu belirlenmiştir. Mogan Gölü’ne, Eymir Gölü’ne ve Ahlatlıbel rekreasyon alanına uzaklığın $0,8-3,2 \mathrm{~km}$ arasında olduğu bölgelerin ise, rekreasyon tesis ve hizmetlerine uzaklık bakımından yarı kentsel rekreasyon ortamı sınıfında olduğu belirlenmiştir (Şekil 5). 


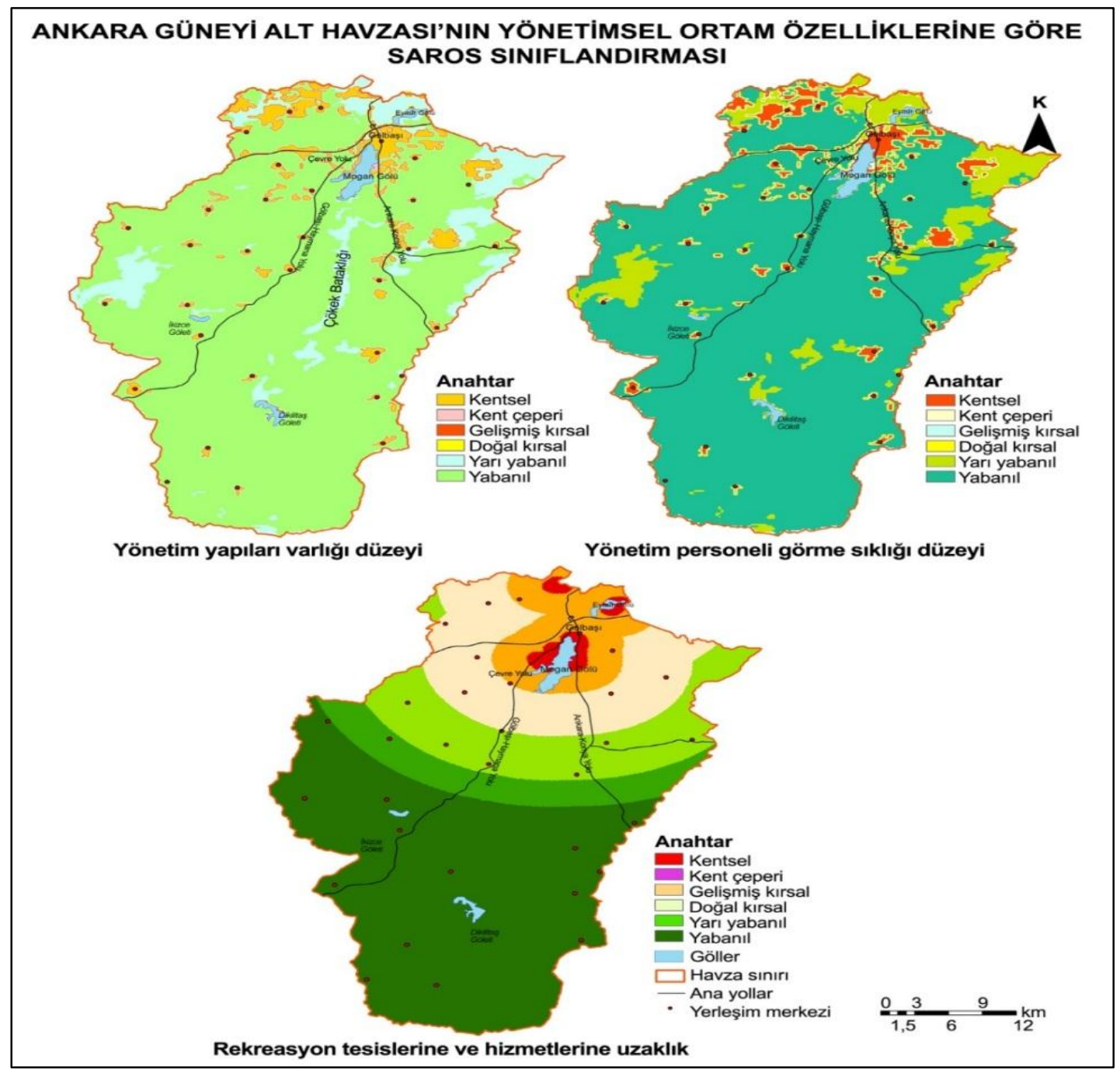

Şekil 5. Ankara Güneyi Alt Havzası'nın yönetimsel ortam özelliklerine göre SAROS sınıflandırılması

Ankara Güneyi Alt Havzası'nın Su ve Arazi Tabanlı Rekreasyon Olanakları Sinifları

Havza'nı her bir ortam parametresinin ağırlıklandırılarak çakıştırılması sonucu, Havza'nın büyük bir bölümünün (78057 ha)- kuzeyde, Eymir Gölü çevresinde, iç ve güney kesimlerinde- yarı yabanıl karakterde rekreasyonel ortam sinıfinda olduğu tespit edilmiştir (Şekil 6, Çizelge 10). Yarı yabanıl karakterdeki bu alanlar, Ankara kentsel alanından ve Gölbaşı ilçe merkezinden uzakta, kırsal yerleşimlerin az olduğu, tarım dışında, insan faaliyetlerinin çok düşük düzeyde ve doğallık hissinin hakim olduğu alanlardır. Havza'da, yarı yabanıl karakterde rekreasyonel olanaklarına sahip alanların ardından, alansal büyüklük bakımdan ikinci sırada; doğal kırsal karakterde rekreasyon ortam özelliklerine sahip alanlar gelmektedir (30933 ha) (Şekil 6). Doğal ve kırsal yaşamın içiçe, yönetimin sınırlı ve rekreasyon hizmetlerinin çok düşük olduğu doğal kırsal rekreasyon ortamı; Havza'nın kuzey batısında, kuzey doğusunda ve iç kesimlerinde önemli bir yer kaplamaktadır. Mogan Gölü güneyindeki Güney
Sazlıkları ve Çökek Bataklığı ile Havza'nın kuzeydoğu ve batısında dar bir alanda yayılış gösteren doğal çayırlık alanlar (9238 ha), araştırma alanında yabanıl rekreasyonel ortam sınıfındaki önemli doğal alanlardır. Alanın kuzeyinde ve kuzey batısında (Mogan Gölü kuzeyi ve kuzeydoğusu, Ahlatlıbel ve Incek çevresi), rekreasyon hizmetlerine yakınlığın, rekreasyon çeşitliliğinin, ziyaretçi yoğunluğunun ve yönetim personeli görme slklığının yüksek olduğu bölgelerin; kentsel (4662 ha) ve kent çeperi (1814 ha) sinıfında rekreasyonel ortamlar olduğu tespit edilmiştir (Şekil 6).

\section{TARTIŞMA ve SONUÇ}

Rekreasyondan arzu edilen deneyimin sağlamasında, rekreasyon olanakları en önemli faktörlerden biridir. Rekreasyon olanaklarını ve deneyimini biçimlendiren, en önemli bileşenler ise; fiziksel, sosyal ve yönetsel ortam koşullarıdır. 


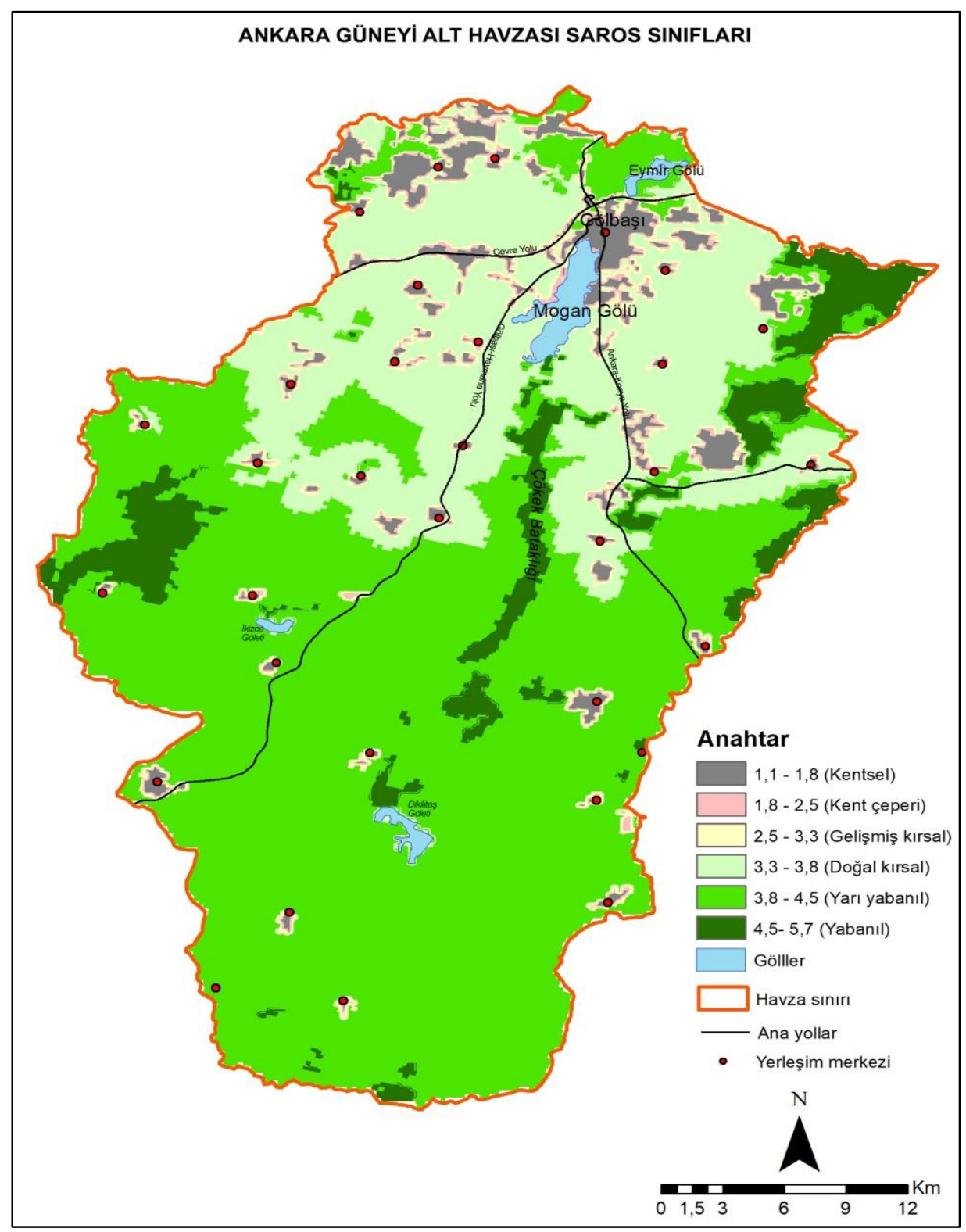

Şekil 6. Ankara Güneyi Alt Havzası SAROS sınıfları

Çizelge 10. Ankara Güneyi Alt Havzası SAROS sınıflarının alansal ve \% dağılımı

\begin{tabular}{lll}
\hline SAROS Sınıf & Alan büyüklüğü (ha) & $\%$ \\
\hline Kentsel & 4662 & 3,6 \\
\hline Kent çeperi & 1814 & 1,4 \\
\hline Gelişmiş kırsal & 3385 & 2,62 \\
\hline Doğal kırsal & 30933 & 23,92 \\
\hline Yarı yabanıl & 78057 & 60,36 \\
\hline Yabanıl & 9238 & 7,1 \\
\hline
\end{tabular}

Arazi ve su kaynaklarının biçimlendirdiği bir peyzajda, rekreasyon faaliyetinde bulunanlara ve rekreasyon planlaması ve yönetiminden sorumlu olan taraflara rehberlik etmek üzere SAROS yaklaşımı, önemli bir rekreasyon olanakları envanteri, değerlendirme ve planlama aracı olarak öne çıkmaktadır. SAROS aynı zamanda, rekreasyon olanakları hakkında detaylı bilgi sağlamasına bağlı olarak rekreasyon ihtiyaç ve deneyimlerinde, alan ziyaretçilerine de rehberlik etmektedir. Bu çalışmanın temel amaci; Ankara Güneyi Alt Havzası su ve arazi kaynaklarının, alanla ilişkili ve üst ölçekte Ankara ilinin rekreasyon planlama ve yönetim çalışmalarına rehberlik etmek üzere, SAROS yöntemi ile tanımlanmasıdır. $\mathrm{Bu}$ amaçla, ilgili karar alma süreçlerinin desteklenmesi, mevcut rekreasyon ortam 
özelliklerinin ve olanaklarının belirlenmesi için Havza'nın rekreasyon olanakları, fiziksel, sosyal ve yönetimsel ortam özellikleri kapsamında; arazi incelemeleri, uzman değerlendirmesi ve ARCGIS 10.2 ortamında gerçekleştirilen mekansal analizler kapsamında tanımlanmış ve değerlendirilmiştir. Bu süreçte belirlenen her bir ortam özelliği için üretilen haritalar, alanın rekreasyonel planlaması ve yönetimine rehberlik edebileceği gibi, alana yönelik gelecek yönetim ve politika seçeneklerinin etkilerinin değerlendirmesi için de kullanılabilecektir. Araştırmanın havza sınırlarında yürütülmesi, rekreasyon planlama ve yönetim önerilerinin bölgesel bir yaklaşımla ve alanla ilgili diğer kullanım plan ve politikaları ile de ilişkilendirilebilecek biçimde belirlenebilmesini sağlamıştır. Analizler kapsamında elde edilen bulgular, Ankara Güneyi Alt Havzası'nın, yabanıldan kentsele kadar çeşitlilik gösteren farklı rekreasyon ortam özellikleri ve olanakları ile hem Havza'da yaşayan kullanıcıların hem de Ankara kentsel alanından gelen ziyaretçilerin, farklı rekreasyon ihtiyaçlarına ve taleplerine karşılık verebilecek potansiyele sahip olduğunu göstermektedir. Havza'nın büyük bölümünün yarı yabanıl rekreasyonel ortam sinifinda olduğunun belirlenmesi, kullanıcıları için özellikle, kentsel yaşamdan uzak, doğayla içiçe zaman geçirerek sakinliği, ıssızlığı ve doğayı deneyimleyebilecekleri, fiziksel ve psikolojik olarak yenilenebilecekleri bir alan olduğunu göstermektedir. $\mathrm{Bu}$ potansiyelleri çerçevesinde Havza'nın yarı yabanıl sınıftaki orta ve güney bölümlerinde, küçük ölçekli rekreasyon alt yapısı ve ziyaretçilerin çoğunlukla kendi olanakları ile gerçekleştirebilecekleri, doğayı tanımaya odaklı ve macera duygularının tatmin edilmesine yönelik, ekoturizm faaliyetleri planlanmalıdır. Bununla birlikte, yarı yabanıl sınıftaki bu alanlarda (örn: Eymir Gölü ve çevresi), doğal yapının ve süreçlerin korunması için ziyaretçi yoğunluğunu sinırlandırılmasına ve ekosistem sağlığının izlenmesine yönelik önlemler alınmalıdır.

Havza'nın kuzey-batı ve kuzey-doğu bölümlerinin büyük oranda doğal kırsal sınıfta olduğunun belirlenmesi; bu bölgelerin, kullanıcıları için doğayı, kırsal yaşamı ve Ankara'nın kırsal yaşam kültürünü deneyimleyebilecekleri bir alan olduğunu göstermektedir. Buna göre bu bölgeler, günübirlik ya da hafta sonu gerçekleştirilebilecek, ekoturizm, kırsal turizm ve tarım turizm kapsamındaki rekreasyonel faaliyetler için uygun alanlardır. $\mathrm{Bu}$ bölgelerde planlanabilecek faaliyetler; kuş gözlemciliği, fotoğrafçılık, kampçılık, Mogan Gölü'nde sportif balıkçılık, kanoculuk ve güneşlenme olabileceği gibi, kırsal ve tarım turizmi kapsamında gerçekleştirilebilecek; çiftlik ziyaretleri, çiftliklerde konaklama, kendin topla faaliyetleri, ağaç kiralama, hobi bahçeciliği, organik ürün yetiştirme, gibi faaliyetler de olabilir. Bununla birlikte, bu doğal ve kırsal alanların sürdürülebilirliği için özellikle Mogan Gölü kuzeyinde ve batısında, doğal sistem ve öğelerin korunmasına, yapılaşma ve ziyaretçi yoğunluğunun sinırlandırılmasına yönelik önlemler alınması gerekmektedir.

Havza'da yabanıl sinıfta olduğu belirlenen, Mogan Gölü güneyindeki Çökek Bataklığı ve Güney Sazlıkları; doğal yapısı, doğal kaynakların düşük değişim düzeyi ve insan faaliyetlerinden ve etkilerinden uzaklığı ile kullanıcıları için kentsel yaşamdan uzaklaşarak, sulak alan ekosistemi içinde, tek başlarına, yanlız kalarak doğayı deneyimleyebilecekleri ve gözlemleyebilecekleri olanaklar sunmaktadır Basit rekreasyon alt yapısının bile bulunmaması gereken bu alanlarda, araç girişine izin verilmemeli, doğal malzemeden yapılan yönlendirme öğeleri kullanılmalı ve ziyaretçi yoğunluğunun çok düşük olması sağlanmalıdır. Bu bölgelerde sulak alan yönetim faaliyetleri uygulanarak, doğal yapının ve süreçlerin korunmasına ve izlenmesine öncelik verilmelidir. Havza'nın kuzeyinde, Mogan Gölü çevresinin kentsel ve kent çeperi rekreasyonel ortam sinıfı özelliklerini göstermesi, Gölbaşı ÖÇKB’nin bu bölümünde ekosistem işlevlerinin risk altında olduğunu düşündürmektedir. Buna bağlı olarak, Havza'nın bu bölümünde doğal yapı diğer bölümlere göre daha hassas durumdadır. Bu bağlamda, doğa koruma faaliyetlerine öncelik verilmesi gereken Mogan Gölü çevresinde, kentsel rekreasyon çeşitliliği sınırlandırılmalı ve bunun yerine, kent çeperi ve doğal kırsal ortam sınıfına uygun rekreasyon olanaklarının gelişmesi sağlanmalıdır.

Havza'nın büyük bölümünün, fiziksel ve sosyal ortam özellikleri bakımından doğal kırsal ve gelişmiş kırsal rekreasyon ortamı özellikleri göstermesine rağmen, yönetimsel özellikler bakımından yarı yabanıl ve yabanıl özellikler göstermesi; Havza'nın fiziksel ve sosyal ortam özellikleri ile yönetimsel özellikleri arasında uyumsuzluk olduğunu göstermektedir. Bu bağlamda, alanda hem rekreasyon yönetimi hem de doğa koruma alt yapısının ve uygulamalarının güçlendirilmesine ve birbirleriyle uyumlu olmasina özen gösterilmelidir. Bu kapsamda, Havza'nın rekreasyon planlaması ve yönetiminin genel hedefi; Havza genelinde rekreasyon kaynaklarının; doğal ve kültürel peyzaj öğe ve süreçlerinin sürdürülebilirliğinin sağlanması olmalıdır. $\mathrm{Bu}$ bağlamda, araştırmada belirlenen SAROS sınıflarının dikkate alınması; Ankara Metropolitan alanına yakınlığı, sahip olduğu doğal ve yapay su ortamları, arazi formu, biyoçeşitlilik zenginliği ve manzara etkileyiciliği ile rekreasyon için oldukça önemli olan Havza'nın, hem Havza'da hem de Ankara kentinde ve yakın çevresinde yaşayan, boş zamanlarını doğal ve kırsal alanlarda geçirmek isteyen kullanıcıların 
rekreasyon ihtiyaçlarını bugün olduğu gibi gelecekte de karşılayabilmesini sağlayacaktır. Belirlenen rekreasyon ortam sinıfları çerçevesinde geliştirilen önerilerin dikkate alınmasi; Havza'nın kullanıcılarının rekreasyon deneyiminin kalitesini iyileştireceği gibi, bu kişilerin Havza ve Ankara ile duygusal ve düşünsel ilişkilerini de olumlu yönde etkileyebilecektir. Bu öneriler aynı zamanda, alanın ekonomik ve sosyal yapisina da olumlu katkı sağlayabilecektir. Bu bağlamda Havza'da, araştırma kapsamında belirlen rekreasyon sınıflarını ve önerileri dikkate alan rekreasyonel planlama ve yönetimi, hem sakinlerinin hem dışardan gelen kullanıcılarının yaşam kalitelerinin iyileşmesine katkı sağlayabilecektir.

Araştırma kapsamında bütçe ve zaman kısıtlamaları nedeniyle, rekreasyonun öznesi olan kullanıcıların, alanla ilişkili görüşlerinin, rekreasyonel talep ve tercihlerinin, saptanmasina yönelik incelemeler yapılamamıştır. $\mathrm{Bu}$ durum çalışmanın sinırlılıklarından birisidir. Bu bağlamda, SAROS yöntemi ile farklı alanlarda ya da Ankara Güneyi Alt Havza'sının rekreasyon olanakları konusunda yapılacak gelecekteki araştırmalarda, kullanıcıların rekreasyon tutum, beklenti ve ihtiyaçlarını tespit etmeye yönelik verilerin elde edilmesi ve değerlendirilmesi, SAROS yönteminin uzman değerlendirmesi ağırlıklı yapısına kullanıcı değerlendirmelerinin dahil edilmesini sağlayacaktır. Böylece, mevcut rekreasyon olanaklarına ait bilgiler ile kullanıcı eğimlerine yönelik bilgilerin birlikte değerlendirildirildiği etkin rekreasyon yönetimi sistemlerinin geliştirilmesine yönelik araştırma ve uygulamalara katkı sağlanabilecektir.

\section{KAYNAKLAR}

Andkjær S, Arvidsen J 2015. Places for active outdoor recreation - a scoping review. Journal of Outdoor Recreation and Tourism, 12: 25-46.

Anonymous 1998. Recreation Opportunity Spectrum Inventory: Procedures and Standards Manual. The British Columbia Resources Inventory Committee, Version

3. https://www2.gov.bc.ca/assets/gov/environment/nat ural-resource-stewardship/standardsguidelines/risc/ros.pdf. (Erişim tarihi: 15.01.2018).

Anonymous 2018. CORINE 2012 Land Cover. https://land.copernicus.eu/pan-european/corineland-cover/view_. (Erişim tarihi:17.02.2018).

Aukerman R 2011. Water and Land Recreation Opportunity Spectrum (WALROS) Users' Guidebook. CO: US Department of the Interior. Denver.
Finley MT 1990. McDonald Forest: A Case Study in the Use of the Recreation Opportunity Spectrum Planning Framework in a Near-Urban Forest, A Thesis submitted to Oregon State University. http://ir.library.oregonstate.edu/xmlui/bitstream/h andle/1957/10274/ Finley_ Marlene _T_1990.pdf? sequence $=1 \&$ origin $=$ publication_detai l. (Erişim tarihi: 08.04.2018).

Gürer N 2014. Rekreasyon Alanlarının Tasarlanmasinda Temel İlkeler, Ankara Eymir Gölü Örneği. Journal of Recreation and Tourism Research, 1 (2):1-17.

Harshaw HW, HBOR BA, Meitner MJ 2015. Recreation Management. Faculty of Forestry University of British Columbia. Forestry Handbook For British Columbia. https://www.researchgate. net/profile/Howard_Harshaw/publication/26783732 5_RECREATION_MANAGEMENT/links/54f74545 0cf210398e926ecb.pdf. (Erişim tarihi: 31.07.2018).

Karahan F, Orhan T 2009. Çoruh Havzası Uzundere Vadisi'nin Kirsal Rekreasyon Planlaması Yönünden Suya Dayalı Olanakları. Rural Environment Yearbook, Rural Environment and Forestry Issues Research Association, Ankara.

Manfredo MJ, Driver BL, Tarrant MA 1996. Measuring Leisure Motivation: A Meta-Analysis of the Recreation Experience Preference Scales. Journal of Leisure Research, 28(3): 188-213.

Manning RE, Anderson LE 2012. Parks and Outdoor Recreation. (Managing Outdoor Recreation: Case Studies in The National Parks, CABI International, UK: Ed.Manning RE, Anderson LE), 3-9.

More T A, Bulmer S, Henzel L, Mates AE 2003. Extending the Recreation Opportunity Spectrum to nonfederal lands in the Northeast: An implementation guide. Gen. Tech. Rep. NE-309. Newtown Square, PA: U.S. Department of Agriculture, Forest Service, Northeastern Research Station. 25 p.

Soykan F 2000. Kırsal turizm ve Avrupa'da kazanılan deneyim. Anatolia Turizm Araştırmaları Dergisi, 11: 21-33.

Stenseke M, Hansen, AS 2014. From rhetoric to knowledge based actions-Challenges for outdoor recreation management in Sweden. Journal of Outdoor Recreation and Tourism, 7-8: 26-34.

Tanrıvermiş E 2000. Ankara Koşullarında Suya Dayalı Rekreasyon-Spor Faaliyetlerinin Planlanması Üzerine Bir Araştirma. Ankara Üniversitesi, Fen Bilimleri Ensitüsü, Peyzaj Mimarlığı ABD, Doktora Tezi, s.342. 